\title{
10Be inventories in Alpine soils and their potential for dating land surfaces
}

\author{
Egli, M ; Brandova, D ; Böhlert, R ; Favilli, F ; Kubik, P W
}

\begin{abstract}
To exploit natural sedimentary archives and geomorphic landforms it is necessary to date them first. Landscape evolution of Alpine areas is often strongly related to the activities of glaciers in the Pleistocene and Holocene. At sites where no organic matter for radiocarbon dating exists and where suitable boulders for surface exposure dating (using in situ produced cosmogenic nuclides) are absent, dating of soils could give information about the timing of landscape evolution. This paper explores the applicability of soil dating using the inventory of meteoric 10Be in Alpine soils. For this purpose, a set of 6 soil profiles in the Swiss and Italian Alps was investigated. The surface at these sites had already been dated (using the radiocarbon technique or the surface exposure determination using in situ produced $10 \mathrm{Be})$. Consequently, a direct comparison of the ages of the soils using meteoric 10Be and other dating techniques was made possible. The estimation of $10 \mathrm{Be}$ deposition rates is subject to severe limitations and strongly influences the obtained results. We tested three scenarios using a) the meteoric 10Be deposition rates as a function of the annual precipitation rate, b) a constant 10Be input for the Central Alps, and c) as b) but assuming a pre-exposure of the parent material. The obtained ages that are based on the 10Be inventory in soils and on scenario a) for the 10Be input agreed reasonably well with the age using surface exposure or radiocarbon dating. The ages obtained from soils using scenario b) produced ages that were mostly too old whereas the approach using scenario c) seemed to yield better results than scenario b). Erosion calculations can, in theory, be performed using the 10Be inventory and 10Be deposition rates. An erosion estimation was possible using scenario a) and c), but not using b). The calculated erosion rates using these scenarios seemed to be plausible with values in the range of $0-57 \tilde{A} c \hat{A} \hat{A} \mathrm{~mm} / \mathrm{ky}$. The dating of soils using 10Be has several potential error sources. Analytical errors as well as errors from other parameters such as bulk soil density and soil skeleton content have to be taken into account. The error range was from 8 up to 21. Furthermore, uncertainties in estimating 10Be deposition rates substantially influence the calculated ages. Relative age estimates and, under optimal conditions, absolute dating can be carried out. Age determination of Alpine soils using 10Be gives another possibility to date surfaces when other methods fail or are not possible at all. It is, however, not straightforward, quite laborious and may consequently have some distinct limitations.
\end{abstract}

DOI: https://doi.org/10.1016/j.geomorph.2010.02.019

Posted at the Zurich Open Repository and Archive, University of Zurich

ZORA URL: https://doi.org/10.5167/uzh-42967

Journal Article

Accepted Version

Originally published at:

Egli, M; Brandova, D; Böhlert, R; Favilli, F; Kubik, P W (2010). 10Be inventories in Alpine soils and their potential for dating land surfaces. Geomorphology, 119(1-2):62 - 73. 
DOI: https://doi.org/10.1016/j.geomorph.2010.02.019 


\section{$1{ }^{10} \mathrm{Be}$ inventories in Alpine soils and their potential for dating land sur-}

\section{2 faces}

3

4 Markus Egli ${ }^{1}$, Dagmar Brandová ${ }^{1}$, Ralph Böhlert ${ }^{1}$, Filippo Favilli ${ }^{1}$, Peter W. Kubik ${ }^{2}$

5

11 Abstract

12 To exploit natural sedimentary archives and geomorphic landforms it is necessary to date them first.

13 Landscape evolution of Alpine areas is often strongly related to the activities of glaciers in the

${ }^{1}$ Department of Geography, University of Zurich, CH-8057 Zurich, Switzerland

${ }^{2}$ Institute of Ion Beam Physics, ETH Zurich, CH-8093 Zurich, Switzerland

*E-mail to the corresponding author: markus.egli@geo.uzh.ch

Pleistocene and Holocene. At sites where no organic matter for radiocarbon dating exists and where suitable boulders for surface exposure dating (using in situ produced cosmogenic nuclides) are absent, dating of soils could give information about the timing of landscape evolution. This paper explores the applicability of soil dating using the inventory of meteoric ${ }^{10} \mathrm{Be}$ in Alpine soils. For this purpose, a set of 6 soil profiles in the Swiss and Italian Alps was investigated. The surface at these sites had already been dated (using the radiocarbon technique or the surface exposure determination using IN SITU produced ${ }^{10} \mathrm{Be}$ ). Consequently, a direct comparison of the ages of the soils using METEORIC ${ }^{10} \mathrm{Be}$ and other dating techniques was made possible. The estimation of ${ }^{10} \mathrm{Be}$ deposition rates is subject to severe limitations and strongly influences the obtained results. We tested three scenarios using a) the meteoric ${ }^{10} \mathrm{Be}$ deposition rates as a function of the annual precipitation rate, b) a constant ${ }^{10} \mathrm{Be}$ input for the Central Alps, and c) as b) but assuming a pre-exposure of the parent material. The obtained ages that are based on the ${ }^{10} \mathrm{Be}$ inventory in soils and on scenario a) 
26 for the ${ }^{10} \mathrm{Be}$ input agreed reasonably well with the age using surface exposure or radiocarbon dating.

27 The ages obtained from soils using scenario b) produced ages that were mostly too old whereas the approach using scenario c) seemed to yield better results than scenario b). Erosion calculations can,

29 in theory, be performed using the ${ }^{10} \mathrm{Be}$ inventory and ${ }^{10} \mathrm{Be}$ deposition rates. An erosion estimation was possible using scenario a) and c), but not using b). The calculated erosion rates using these sce31 narios seemed to be plausible with values in the range of $0-57 \mathrm{~mm} / \mathrm{ky}$. The dating of soils using

${ }^{10} \mathrm{Be}$ has several potential error sources. Analytical errors as well as errors from other parameters such as bulk soil density and soil skeleton content have to be taken into account. The error range was from 8 up to $21 \%$. Furthermore, uncertainties in estimating ${ }^{10} \mathrm{Be}$ deposition rates substantially influence the calculated ages. Relative age estimates and, under optimal conditions, absolute dating can be carried out. Age determination of Alpine soils using ${ }^{10} \mathrm{Be}$ gives another possibility to date surfaces when other methods fail or are not possible at all. It is, however, not straightforward, quite laborious and may consequently have some distinct limitations.

Keywords: Meteoric ${ }^{10} \mathrm{Be}$, dating, alpine soils, weathering, erosion

Introduction

The analysis and dating of climate-related natural archives allows the estimation of past climate conditions and the rates of geomorphologic and other processes, which in turn also serve as a basis for modelling approaches and predictions.

49 Natural terrestrial sediment and soil archives or geomorphic features and landforms in the Alps, 50 such as moraines, roches moutonnées, peat bogs etc., are often bound to glacial activity and may 51 bear long-term paleoclimatic information. Glaciers have shaped the alpine landscape which, in 
many respects, is directly related to ice retreat and re-advance phases that occurred in the Pleistocene and Holocene. Since the initial work of Penck and Brückner (1909) on Alpine glaciations and the structure of glacier retreat, numerous authors have worked on ice-age stratigraphy (e.g. Keller and Krayss, 1993; Florineth, 1998; Schlüchter, 2004; van Husen, 2004; Ivy-Ochs et al., 2006a,b, 2007), the Lateglacial period of ice decay (e.g. Maisch, 1981; Schoeneich, 1999; Kerschner et al., 1999; Ivy-Ochs et al., 2004, 2008, 2009) and also in detail on Holocene glacier fluctuations in the Alps (Holzhauser, 1984). Dating of geomorphic features (moraines, peat bogs etc.) has often been performed using the radiocarbon technique. The main problem in ${ }^{14} \mathrm{C}$ dating of alpine soils is the lack of datable organic material or imprecise estimates of the age obtained due to the fact that the soils have been reworked. With the improvements in the dating technique using in situ produced cosmogenic isotopes in rock surfaces (surface exposure dating SED; Lal, 1988) the direct determination of moraine ages (Gosse et al., 1995; Ivy-Ochs et al., 1996) became possible, also at sites not having datable organic material. Since then, a great number of studies have been performed with the aim of dating moraines and associated glacier fluctuations using cosmogenic nuclides (compilation in Reuther et al., 2006), especially ${ }^{10} \mathrm{Be}$. Ivy-Ochs et al. (2006a) provided a summary of exposurederived ages (using ${ }^{10} \mathrm{Be},{ }^{26} \mathrm{Al},{ }^{36} \mathrm{C}$ and ${ }^{21} \mathrm{Ne}$ ) for the Lateglacial with a focus on the European Alps. However, critically reviewed, the absolute chronology is still poorly established. It must be taken into consideration that several limitations sometimes render dating of rock boulders, and consequently land surfaces, difficult. According to Ivy-Ochs and Kober (2008) and Gosse and Philips (2001), the sampled object (boulder, clasts or bedrock) surface must have i) undergone single-stage exposure (negligible pre-exposure/inheritance), ii) been continuously exposed in the same position (not shifted), iii) never been significantly covered with sediment, and iv) undergone only minimal surface weathering or erosion (not spalled). The influence of snow on the boulder age may be, furthermore, very significant and clearly exceeds the influence of surface erosion (Böhlert et al., submitted). 

9

Another technique was developed by Schaller et al. (2009a) who were able to derive age constraints from depth profiles dating (soils) of the situ produced cosmogenic nuclides ${ }^{10} \mathrm{Be}$ in quartz from the $0.5-1.0 \mathrm{~mm}$ fraction. According to these authors, exposure age constraints from boulders are, however, more straightforward for moraines than ages based on depth profile dating. Moraine soils may significantly erode and may be mixed, suggesting that previous weathering and dust accumulation on moraines provide minimum estimates for these processes.

An additional technique is based on the 'meteoric' ${ }^{10} \mathrm{Be}$ inventories in soils. In this case, ${ }^{10} \mathrm{Be}$ is produced via interactions of high-energy cosmic radiation with target nuclei in the atmosphere. Rainfall scavenges meteoric cosmogenic ${ }^{10} \mathrm{Be}$ from the atmosphere. Once on earth, it accumulates in surface deposits over time. Several authors (Monaghan et al., 1983; Pavich et al., 1984; Maejima et al., 2004, 2005) have shown that minimum absolute ages can be derived from the inventory of meteoric ${ }^{10} \mathrm{Be}$ in soil profiles. Using this technique, a variety of soils having ages from about 8 ky to $136 \mathrm{ky}$ could be dated. At sites where suitable organic matter for radiocarbon dating does not exist and where appropriate boulders are absent, dating of soils is essential to give information about the timing of landscape evolution.

This paper explores the potentiality of ${ }^{10} \mathrm{Be}$ inventories (meteoric ${ }^{10} \mathrm{Be}$ ) for dating soils in alpine environments. The obtained ages using this methodology could be directly compared with those derived either from surface exposure or from radiocarbon analyses of geomorphic land surfaces. Consequently, it was possible to perform a calibration study.

\section{Study sites}

Six soil profiles in the Swiss and Italian Alps were selected (Table 1; Figs. 1, 2). The sites have previously-published datasets (soil chemical and physical aspects as well as dating; see Tables 2 4). The landscape near the investigation areas has been strongly influenced by former glaciers (Fig. 
1) and all the soils (Fig. 2) developed on lateral, recessional or ground moraines consisting of silica-

104 tic material (granite or gneiss). Several distinct morainic complexes characterise the readvance 105 phases in the Lateglacial and the Holocene. The timing of deglaciation is known for these sites. The 106 sites became ice-free or were formed in the Holocene and Late Pleistocene (about 3 - 19 ky BP; see 107 Table 4).

108 The sites encompass different climate (from moderate to alpine) and vegetation zones (mixed forest 109 to alpine grassland). Cambisols or Podzols (IUSS working group WRB, 2006) are the main soil 110 types.

111 A number of studies have already been performed in and around the investigated regions (Fitze, 112 1982; Wipf, 2001; Egli and Mirabella, 2001; Zanelli, 2002; Egli et al., 2002, 2003; Maisch et al., 113 2005; Favilli et al., 2009, 2010; Böhlert et al., submitted). At the investigation areas, Val Mulix 114 (Switzerland), Val di Rabbi (Trentino; Italy) and Schmadri (Switzerland), a wide range of relative 115 and numerical techniques have been applied to date the surfaces (Egli and Mirabella, 2001; Favilli 116 et al., 2009; Böhlert et al., submitted). Radiocarbon dating of peat bogs, buried soils, charcoal frag117 ments and organic residues in soils or ${ }^{10} \mathrm{Be}$ dating of large boulders having prominent quartz veins 118 was performed. Geomorphologic mapping was carried out by Maisch (1981) in the Val Mulix and 119 Albula regions and by Wipf (2001) in the Schmadri region, based on moraine morphology, their 120 morphostratigraphic position and ELA (equilibrium line altitude) depression values. Moraines and 121 roches moutonnées were dated by SED using ${ }^{10} \mathrm{Be}$ (the boulders were chosen in the closest vicinity 122 of the investigated soils; Favilli et al., 2009; Böhlert et al., submitted).

Materials and methods 
128 As soil horizons can be considered to be compartments having typical chemical and mineralogical 129 processes, sampling was bound to the morphology of the soils. Around two to four kilograms of soil 130 material (Hitz et al., 2002) were collected per soil horizon from 6 soil pits. Soil bulk density was 131 determined by a soil core sampler (or by excavated holes having a volume of about $500-2000 \mathrm{ml}$ 132 that were backfilled with a measurable volume of quartz sand). Undisturbed soil samples were 133 taken down to the $\mathrm{BC}$ or $\mathrm{C}$ horizon.

\section{Soil chemistry and physics}

136 The soil samples were air-dried: large aggregates being gently broken by hand and sieved to $<2$ $137 \mathrm{~mm}$. Total $\mathrm{C}$ and $\mathrm{N}$ contents of the soil were measured by $\mathrm{C} / \mathrm{H} / \mathrm{N}$ analyser (Elementar Vario EL, 138 Elementar Analysensysteme $\mathrm{GmbH}$ ) using oven-dried and ball-milled fine earth. Total C corre139 sponds in our case to organic $\mathrm{C}$ due to the absence of any carbonates in the soil. Soil $\mathrm{pH}$ (in $0.01 \mathrm{M}$ $140 \mathrm{CaCl}_{2}$ ) was determined on air-dried samples of the fine earth fraction using a soil solution ratio of 141 1:2.5. The oxalate-extractable iron and aluminium fractions $\left(\mathrm{Fe}_{\mathrm{o}}, \mathrm{Al}_{\mathrm{o}}\right)$ were determined according to 142 McKeague et al. (1971) and analysed by AAS (Atomic Absorption Spectrometry - AAnalyst 700, 143 Perkin Elmer, USA). After a pre-treatment of the samples with $\mathrm{H}_{2} \mathrm{O}_{2}(3 \%)$, particle size distribution 144 of the soils was measured using a combined method consisting of sieving coarser particles (2000 $14532 \mu \mathrm{m})$ and measurement of the finer particles $(<32 \mu \mathrm{m})$ by means of an X-ray sedimentometer 146 (SediGraph 5100, Micromeretics, Norcross, GA, USA).

\section{Age deternination of soils using meteoric ${ }^{10} \mathrm{Be}$}

149 The inventory of meteoric ${ }^{10} \mathrm{Be}$ in a soil can be directly related to the soil age (Maejima et al., 2007; 150 Tsai et al., 2007). The ${ }^{10} \mathrm{Be}$ abundance in a soil profile was estimated assuming that the overwhelm151 ing part of ${ }^{10} \mathrm{Be}$ is adsorbed in the fine earth fraction. The amount is consequently calculated ac152 cording to: 


$$
N=\sum_{a=1}^{n}\left(z_{w} \rho_{w} C_{w} f_{w}\right)
$$

154 where $N$ corresponds to the abundance of ${ }^{10} \mathrm{Be}$ (inventory), $z_{\mathrm{w}}$ to the thickness of the corresponding 155 soil horizon, $\rho_{\mathrm{w}}$ being the bulk density, $C_{w}$ to the concentration (fine earth) in the corresponding 156 horizon and $f_{\mathrm{w}}$ to the relative fraction ( $\%$ by weight) of fine earth.

157 If the ${ }^{10} \mathrm{Be}$ inventory since the initiation of soil formation is known, then the time soils were ex158 posed to meteoric ${ }^{10} \mathrm{Be}$ flux can be determined using the following equation:

$$
\begin{gathered}
\frac{d N}{d t}=q-\lambda N, \text { with } \mathrm{N}=0 \text { at } \mathrm{t}=0 \\
t=-\frac{1}{\lambda} \ln \left(1-\lambda \frac{N}{q}\right)
\end{gathered}
$$

161 where $t$ is the age of soil, $\lambda$ is the decay constant of ${ }^{10} \mathrm{Be}\left(4.62 \times 10^{-7} / \mathrm{y}\right), N$ is the inventory of ${ }^{10} \mathrm{Be}$ 162 in time $t$ (atoms $/ \mathrm{cm}^{2}$ ) and $q$ is the annual deposition rate of ${ }^{10} \mathrm{Be}$ (atoms $/ \mathrm{cm}^{2} / \mathrm{y}$ ). The measured in163 ventory $N$ is the integral of concentration multiplied by soil density at the depth the profile was 164 sampled (Pavic and Vidic, 1993; Maejima et al., 2004).

\section{${ }^{10}$ Be measurement of soil samples}

167 To measure the abundance of ${ }^{10} \mathrm{Be}$ in the six profiles, the individual soil horizons (see Table 2 ) were 168 analysed for their ${ }^{10} \mathrm{Be}$ concentration in the fine earth (fraction $<2 \mathrm{~mm}$ ). ${ }^{10} \mathrm{Be}$ was extracted from the 169 soil samples using a modified method from Horiuchi et al. (1999). $0.4 \mathrm{mg}$ of ${ }^{9} \mathrm{Be}\left(\mathrm{NO}_{3}\right)_{2}$ (carrier) 170 was added to $1-5 \mathrm{~g}$ of soil $(<2 \mathrm{~mm}$ fraction). This mixture of carrier and sample was then heated 171 for $3 \mathrm{~h}$ at $550^{\circ} \mathrm{C}$ to remove organic matter. After cooling it was put in a shaker and leached with 8 $\mathrm{ml} \mathrm{HCl}(16 \% \mathrm{v} / \mathrm{v})$ overnight. The solid part was separated by centrifuge and leached again: the liq-

173 uid was collected. After a second leaching, the soil residue was disposed of and the obtained solu174 tions mixed together and heated at $80^{\circ} \mathrm{C}$ until the volume reduced to c. $1 \mathrm{ml}$. To this sample, $1 \mathrm{ml}$ $175 \mathrm{HNO}_{3}(65 \% \mathrm{v} / \mathrm{v})$ and $1 \mathrm{ml} \mathrm{HCl}(32 \% \mathrm{v} / \mathrm{v})$ were added and any fine particles removed by centrifuga176 tion. $\mathrm{NaOH}(16 \% \mathrm{v} / \mathrm{v})$ was added to the sample until it reached a $\mathrm{pH}$ value of 2 , when $1 \mathrm{ml}$ of conc. 
EDTA was added. The EDTA solution removes metals (Fe, Mn) in the form of EDTA complexes.

$178 \mathrm{NH}_{4} \mathrm{OH}$ was added until a $\mathrm{pH}$ value of 8 was obtained and the resulting gel containing $\mathrm{Be}(\mathrm{OH})_{2}$, $\mathrm{Al}(\mathrm{OH})_{3}$ and some $\mathrm{Fe}(\mathrm{OH})_{2}$ and $\mathrm{Mn}(\mathrm{OH})_{2}$ was precipitated. $\mathrm{NaOH}$ solution was added to the gel until the $\mathrm{pH}$ value reached 14 . The $\mathrm{Be}(\mathrm{OH})_{2}$ and $\mathrm{Al}(\mathrm{OH})_{3}$ re-dissolved and the solution containing Be and Al was separated by centrifugation. This procedure was repeated a second time to recover any remaining Be. Once again conc. $\mathrm{HCl}(32 \% \mathrm{v} / \mathrm{v})$ was added to the liquid (containing $\mathrm{Be})$ to reach a $\mathrm{pH}$ value of 2 and $1 \mathrm{ml}$ of $10 \%$ EDTA was added to remove the last traces of Fe and $\mathrm{Mn}$. The $\mathrm{Be}(\mathrm{OH})_{2}$ and $\mathrm{Al}(\mathrm{OH})_{3}$ were precipitated with $\mathrm{NH}_{4} \mathrm{OH}$ and subsequently centrifuged. If Fe was still present, the gel would have been coloured yellow. $\mathrm{HCl}(32 \% \mathrm{v} / \mathrm{v})$ was added until the gel redissolved. It was then heated to reduce the volume to c. $1 \mathrm{ml}$. Any Fe was removed using the anion exchange column; the cleaned solution was heated to near dryness. The $\mathrm{Be}$ and $\mathrm{Al}$ were separated using two different cation exchange columns. In the first stage the precipitated gel was dissolved in $\mathrm{HCl}$ and passed through the first cation exchange column where most of the Al was adsorbed. After evaporation and precipitation the $\mathrm{Be}(\mathrm{OH})_{2}$ was dissolved in oxalic acid (stage two) and passed through the second cation exchange column which adsorbed the last traces of Al. This second procedure is based on the formation of $\mathrm{Al}$ complexes with oxalic acid, and $\mathrm{Al}$ is also adsorbed in the column. Pure $\mathrm{Be}(\mathrm{OH})_{2}$ was precipitated with $\mathrm{NH}_{4} \mathrm{OH}$ and subsequently dried at $70{ }^{\circ} \mathrm{C}$. It was calcinated in an oven for $2 \mathrm{~h}$ at $850^{\circ} \mathrm{C}$ to obtain pure $\mathrm{BeO}$. This $\mathrm{BeO}$ was then mixed with $\mathrm{Cu}$ powder and pressed into a mass spectrometer target.

The ${ }^{10} \mathrm{Be} /{ }^{9} \mathrm{Be}$ ratios were measured at the ETH Zurich Tandem Accelerator Mass Spectrometry (AMS) facility (Kubik and Christl, 2009) using ETH AMS standards S555 $\left({ }^{10} \mathrm{Be} /{ }^{9} \mathrm{Be}=95.5 \times 10^{-12}\right.$ nominal) and S2007 $\left({ }^{10} \mathrm{Be} /{ }^{9} \mathrm{Be}=30.8 \times 10^{-12}\right.$ nominal $)$, both associated with a ${ }^{10} \mathrm{Be}$ half-life of 1.51 My.

\section{Statistics}


As the data did not always show a normal distribution, correlation analysis was performed using

203 Pearson's correlation coefficient for normally distributed data and the Spearman's rank correlation coefficient for non-normally distributed ones (Sachs, 1992). A log-transformation of the data was necessary for the multiple regression analysis.

\section{Results}

Physical and chemical soil properties

211 The soils showed an undisturbed evolution (according to their macromorphology as well as their 212 chemical and physical properties) with no signs of erosion or burial. All soils in the study area have 213 a loam or sandy-loam in the topsoil and a loamy-sand texture in the subsoil (Table 2). The 214 acidification of the soils is pronounced with $\mathrm{pH}$-values in the topsoil generally between 3.0 and 4.0 215 (Table 3). Some of the soils showed clear podzolisation features (Tables 2, 3) with an eluviation 216 and illuviation of $\mathrm{Fe}, \mathrm{Al}$ and sometimes soil organic matter (SOM). All soils have a distinct amount 217 of soil skeleton (material with a diameter $>2 \mathrm{~mm}$ ) that usually increases with increasing soil depth 218 (except for the Meggerwald site) and can be up to almost $70 \%$ by weight. These values are typical 219 for moraines in Alpine areas.

\section{${ }^{10} \mathrm{Be}$ in the soil profiles}

222 Meteoric ${ }^{10} \mathrm{Be}$ infiltrates into soils and is adsorbed along the profile. Highest ${ }^{10} \mathrm{Be}$ concentrations in the fine earth (up to $>10 \times 10^{8}$ atoms/g) were measured in the surface horizons. Usually, the ${ }^{10} \mathrm{Be}$ concentrations decreased with increasing soil depth (Fig. 3). At several sites an increase of the ${ }^{10} \mathrm{Be}$ concentration in the $\mathrm{Bs}$ or Bhs horizon was detected, which indicated an active translocation of ${ }^{10} \mathrm{Be}$ within the soil profile. This translocation is due to podzolisation processes where ${ }^{10} \mathrm{Be}$ migrates together with $\mathrm{Fe}, \mathrm{Al}$ and/or SOM to greater soil depths. 
230 To calculate the soil age, the deposition rate of ${ }^{10} \mathrm{Be}$ must be known (see Equations 2 and 3 ). Be231 cause the ${ }^{10} \mathrm{Be}$ deposition rates are unknown for the investigated sites, they had to be estimated. 232 Two different concepts in estimating the ${ }^{10} \mathrm{Be}$ deposition rates exist.

233 1) Maejima et al. (2005) showed that the deposition rate of ${ }^{10} \mathrm{Be}$ is primarily a function of the 234 amount of precipitation. Average concentrations of ${ }^{10} \mathrm{Be}$ in rainfall are near $1-1.5 \times 10^{4}$ atoms $/ \mathrm{cm}^{3}$ 235 (Monaghan et al., 1985/1986; Brown et al., 1989; Maejima et al., 2005). Annual mean ${ }^{10}$ Be concen236 trations in New Zealand rain ranged from 2.1 to $2.9 \times 10^{4}$ atoms $/ \mathrm{cm}^{3}$ (Graham et al., 2003) and in 237 France from about $1.5-4.4 \times 10^{4}$ atoms $/ \mathrm{cm}^{3}$ (Raisbeck et al., 1979). The annual deposition rate for 238 the past thousands of years is mostly unknown. Heikkilä et al. (2008a) considered existing ${ }^{10} \mathrm{Be}$ re239 cords from Greenland and Antarctica and were able to show that slightly increased concentrations 240 were recorded during the Maunder Minimum (MM) period, 1645 - 1715, when solar activity was 241 very low and the climate colder (Little Ice Age). ${ }^{10} \mathrm{Be}$ deposition rates were seemingly subject to 242 some variations in the past. Vonmoos et al. (2006) showed that the measured ${ }^{10} \mathrm{Be}$ fluxes (derived 243 from the GRIP ice core) have some variation, but that the integrated average smoothes the observed 244 variation due to changes in solar activity to a quasi-permanent long-term average value (over the 245 last $10 \mathrm{ky}$ ). ${ }^{10} \mathrm{Be}$ concentrations during the $\mathrm{MM}$ period were about $1.5-1.7 \times 10^{4}$ atoms $/ \mathrm{cm}^{3}$ (in 246 Greenland) and $3.9 \times 10^{4}$ atoms $/ \mathrm{cm}^{3}$ (in Antarctica). The values given by Monaghan et al. $247(1985 / 1986)$ are, therefore, reasonable and were taken for this investigation.

248 2) Willenbring and von Blanckenburg (2009) argue, however, that in coastal and island settings 249 where the atmospheric transport time is fast and ${ }^{10} \mathrm{Be}$ and ${ }^{7} \mathrm{Be}$ concentrations in rain are signifi250 cantly correlated with precipitation rate, the yearly flux of meteoric ${ }^{10} \mathrm{Be}$ is independent of the rain 251 rate. This is, consequently, not in agreement with measurements of Graham et al. (2003) and 252 Maejima et al. (2005). The geometry of the Earth's magnetic field produces a predictable latitudinal 253 variation. The combination of increased flux toward the poles and the increasing thickness of the 
atmosphere for low latitudes and the low pressures at the poles results in a maximum at mid255 latitudes (Willenbring and von Blanckenburg, 2009).

256 To see the effect of the ${ }^{10} \mathrm{Be}$ deposition rates on the measurement of soil age, the age estimation using ${ }^{10} \mathrm{Be}$ in soils was done using both approaches:

- ${ }^{10} \mathrm{Be}$ deposition fluxes derived from the amount of precipitation and

- ${ }^{10} \mathrm{Be}$ deposition fluxes derived from a modelling approach using constant fluxes for the Central Alps (Willenbring and von Blanckenburg, 2009). This modelling approach for the Central Alps yields a deposition rate of about $10 \times 10^{5}$ atom $/ \mathrm{cm}^{2} / \mathrm{y}$ (see also Fig. 4).

Using the first approach, the deposition rates of ${ }^{10} \mathrm{Be}$ in our study sites range from $1.2 \times 10^{6}$ at$\mathrm{oms} / \mathrm{cm}^{2} / \mathrm{y}(1000 \mathrm{~mm} / \mathrm{y}$ rainfall $)$ to $2.4 \times 10^{6}$ atoms $/ \mathrm{cm}^{2} / \mathrm{y}(2000 \mathrm{~mm} / \mathrm{y}$ rainfall $)$. The second approach gives for all sites the same deposition rate of $1.0 \times 10^{6}$ atoms $/ \mathrm{cm}^{2} / \mathrm{y}$ (Table 5).

\section{Age determination using meteoric ${ }^{10} \mathrm{Be}$}

267 In the soils, $120-300 \times 10^{8}{ }^{10} \mathrm{Be}$ atoms $/ \mathrm{cm}^{2}$ are accumulated (Table 5). Errors in the quantification 268 of the ${ }^{10} \mathrm{Be}$ abundance are due to analytical errors (AMS) of ${ }^{10} \mathrm{Be}$ determination and due to density 269 and soil skeleton measurements (Table 5). An estimate of the error range was performed by means 270 of the maximum error. The range of error $\Delta f$ can be estimated by the mean analytical error $\left({ }^{10} \mathrm{Be}\right)$ 271 and the error $\Delta y$ introduced due to soil analyses (density, soil skeleton).

$$
\Delta f=\Delta x+\Delta y
$$

273 The ratio $\Delta f / f_{X, Y}$ (with $f_{X, y}$ as the measured value) gives the relative error that equals the sum of 274 the individual mean errors. The error for the density and the soil skeleton determinations was estimated to be $5 \%$ (for each parameter). In soil horizons having no soil skeleton the corresponding error was considered to be negligible. These assumptions are very conservative (Desaules and Dahinden, 2000). Accordingly, the estimated errors of the ${ }^{10}$ Be inventory and, subsequently, the derived surface ages vary from 8 to c. $21 \%$. 
An additional variability is introduced by the selection of the ${ }^{10} \mathrm{Be}$ deposition rates scenarios (see 280 above). If a ${ }^{10} \mathrm{Be}$ deposition rate which depends on the annual amount of precipitation is used, then 281 the calculated ages vary between 6.0 and $19.2 \mathrm{ky}(=$ scenario (a)). Older ages (= scenario (b)) are 282 obtained (12.6 - 30.3 ky) using a constant meteoric ${ }^{10} \mathrm{Be}$ flux for the Central Alps (Table 5). Ac283 cording to Table 4, the soils have a decreasing age with Meggerwald $>$ Val di Rabbi $>$ Val Mulix $>$ 284 Schmadri profile $1=$ Morteratsch $>$ Schmadri profile 2. Using a precipitation-dependent meteoric $285{ }^{10}$ Be flux (scenario (a)), the following sequence is derived: Meggerwald $>$ Val Mulix $>$ Val di 286 Rabbi $>$ Schmadri profile $1>$ Morteratsch $>$ Schmadri profile 2. This sequence is quite similar to 287 the expected one (see Table 4). Assuming a constant ${ }^{10} \mathrm{Be}$ flux for the Central Alps (scenario (b)) 288 the age decrease is Meggerwald $>$ Schmadri profile $1>$ Val Mulix $>$ Val di Rabbi $>$ Schmadri pro289 file $2>$ Morteratsch. This last sequence differs substantially from the expected one. In theory, it 290 might be that the glacial till (morainic material) was already exposed to the atmosphere or mixed 291 with material that was exposed. Consequently, an additional approach (= scenario (c)) that assumed 292 a pre-exposure was applied. The ${ }^{10} \mathrm{Be}$ concentration in the parent material was assumed to account 293 for this pre-exposure and was consequently subtracted from the measured concentrations in the 294 other soil horizons. The ${ }^{10}$ Be inventory was then calculated on this basis. As in scenario (b), a con295 stant ${ }^{10} \mathrm{Be}$ deposition rate was assumed. Using scenario (c) the following age sequence is derived: 296 Meggerwald $>$ Val Mulix $>$ Schmadri profile $1>$ Val di Rabbi $>$ Schmadri profile $2>$ Morteratsch. 297 This scenario fits slightly better to the expected one than scenario (b), but major discrepancies still 298 exist.

Discussion 
Maejima et al. $(2004,2005)$ observed a positive correlation between the clay content and the ${ }^{10} \mathrm{Be}$ concentration in the soils. The distribution pattern of ${ }^{10} \mathrm{Be}$ along the soil profile could be mainly attributed to the amount of clays. At our sites, such a correlation was not detected $(R=-0.18 ; p>$ 0.1). This might be due to the rather low amount of clays and to the stony character of most of the sites. However, a significant correlation between ${ }^{10} \mathrm{Be}$ and the oxalate-extractable fractions of $\mathrm{Fe}$ $\left(R_{\text {Spearman }}=0.35, p=0.039\right)$ and $\mathrm{Al}\left(R_{\text {Spearman }}=0.37, \mathrm{p}=0.030\right)$ could be found. Furthermore, soil organic matter was significantly correlated with ${ }^{10} \mathrm{Be}\left(R_{\text {Spearman }}=0.46, p=0.007\right)$. The $\mathrm{pH}$-value was correlated only at the $10 \%$ significance level. A log transformation of the datasets made a multiple regression possible. ${ }^{10} \mathrm{Be}$ can be described as:

$$
\log \left[{ }^{10} B e\right]=8.2572-0.239 \log \left[F e_{o}\right]+0.2809 \log \left[A I_{o}\right]+0.3146 \log [\text { org. } C]
$$

314 with $R=0.50$ and $p=0.04$

The distribution pattern and mobility of ${ }^{10} \mathrm{Be}$ within the soil profile are thus controlled to a certain extent by SOM and weakly crystalline oxides and hydroxides.

The great variability of the ${ }^{10} \mathrm{Be}$ depth profiles can be explained by complex geochemical and transport mechanisms (Morris, 1991; Tsai et al., 2008). Eluvial and illuvial transport mechanisms seem to be crucial — in Podzols as well as in Luvisols (where a clay-mediated transport takes place; 321 Pavich et al., 1984; Tsai et al., 2008). Leaching of ${ }^{10} \mathrm{Be}$ from the soil column may lead to an underestimation of the age. Kaolinite and dioctahedral vermiculite, however, seem to be a very efficient trap for ${ }^{10} \mathrm{Be}$ (Pavich et al., 1985). In the investigated soils, smectite, vermiculite, chlorite, mica, kaolinite, HIV (hydroxy-interlayered vermiculites), HIS (hydroxy-interlayered smectites) and interstratified minerals prevail in the clay fraction (Egli and Mirabella, 2001; Egli et al., 2002, 2003; 326 Favilli et al., 2009). Due to the given distribution of ${ }^{10} \mathrm{Be}$ in the soil profiles, a major loss of ${ }^{10} \mathrm{Be}$ with the acidic percolate can be excluded due to the sharp decrease of ${ }^{10} \mathrm{Be}$ with soil depth. A physical movement down-profile of clay particles containing adsorbed ${ }^{10} \mathrm{Be}$ is also rather improbable due to the acidic soil conditions (which usually inhibit clay transport). Furthermore, in all 

oxyhydroxides.

soils the clay content is low and no increase with soil depth could be measured. The highest amount of ${ }^{10} \mathrm{Be}$ is found in the topsoil and $\mathrm{Bs}$ (or Bhs) horizon and seems to be bound to SOM, Fe- and Al-

\section{${ }^{10}$ Be deposition rates}

Probably the most difficult and challenging issue in dating soils using ${ }^{10} \mathrm{Be}$ is the estimation of ${ }^{10} \mathrm{Be}$ deposition rates for a specific site. There is, unfortunately, no consensus to be obtained from the literature of the exact effect of precipitation on the ${ }^{10} \mathrm{Be}$ flux in an area. The variability in the ${ }^{10} \mathrm{Be}$ concentration from precipitation measurements reflects short-term fluctuations in precipitation rate, stratosphere/troposphere exchange, magnetic field strength, etc. (Monaghan et al., 1985/86; Graham et al., 2003, Willenbring and von Blanckenburg, 2009). Several modelling attempts were made to predict ${ }^{10} \mathrm{Be}$ deposition rates on a global scale. Field et al. (2006) used the Goddard Institute for Space Studies ModelE (GISS) general circulation model (GCM) and Heikkilä (2007) used the European Centre Hamburg Model (ECHAM5) GCM in combination with Masarik and Beer's (1999) production functions. Willenbring and von Blanckenburg (2009) listed the measured ${ }^{10} \mathrm{Be}$ deposition rates and modelled values for a few sites (see Fig. 4). In some cases, the model predictions match the measured deposition rates quite well, but in some cases not. It seems that the modelling approach tends to slightly underestimate the deposition rates at high ${ }^{10} \mathrm{Be}$ influxes.

\section{Validity of the ${ }^{10} \mathrm{Be}$ ages}

The calculated ages using ${ }^{10} \mathrm{Be}$ in soils could be compared to available ages of the same geomorphic features (Table 4). The correlation between the ages derived from ${ }^{10} \mathrm{Be}$ measurements and the expected age is given in Fig. 5. The calculated ages using a ${ }^{10} \mathrm{Be}$ deposition rate based on the amount of precipitation (scenario (a)) agree quite well with the expected age of the landform (Fig. 5a). Some discrepancies exist at the site Val di Rabbi where a major difference between the expected age and the ${ }^{10} \mathrm{Be}$-age of the soil was detected and at the site Schmadri (profile 2) where instead of 
$3.6 \mathrm{ky}$ an age of $6.0 \mathrm{ky}$ was calculated. Erosion, leaching and accumulation processes in soils affect 357 the calculated ${ }^{10} \mathrm{Be}$-age (Lal, 2001; Maejima, 2005; Tsai et al., 2008). Erosion eliminates accumu358 lated ${ }^{10} \mathrm{Be}$. In addition, the soil components interact with percolating acidic solutions and, as a con359 sequence, adsorbed ${ }^{10} \mathrm{Be}$ may move out of the considered system (Tsai et al., 2008). Both processes 360 lead to an underestimation of the age. In contrast, accumulation of soil material imports ${ }^{10}$ Be. Fur361 thermore, soil material may have been pre-exposed and consequently a too high amount of meteoric $362{ }^{10}$ Be may have accumulated. This last process has most probably occurred at the Schmadri profile 2 363 site. The moraine here was formed due to a small re-advance of the glacier (Wipf, 2001) 3600 y BP. 364 After the Egesen glacial state (Younger Dryas; $11 \mathrm{ky} \mathrm{BP),} \mathrm{the} \mathrm{glacier} \mathrm{retreated} \mathrm{rapidly} \mathrm{to} \mathrm{the} \mathrm{pre-}$ 365 sent-day situation. As the re-advance occurred around 3600 y BP, we hypothesise that pre-exposed 366 material (having an age of about $11 \mathrm{ky}$ ) was probably mixed with fresh, un-weathered material.

367 The ages calculated assuming a constant meteoric ${ }^{10} \mathrm{Be}$ flux (scenario (b)) agreed in only two cases 368 with the age obtained from SED or radiocarbon dating (sites Morteratsch and Val di Rabbi; Fig. $3695 \mathrm{~b}$ ). For all other sites, the estimated ages of the soils were definitely too old. An almost similar age 370 for Meggerwald (which is definitely the oldest soil) and Schmadri profile 1 (which corresponds to 371 the Egesen glacial stage; Wipf, 2001) was derived. In our case, using the approach with a constant 372 meteoric ${ }^{10} \mathrm{Be}$ influx, the results obtained were not reasonable. The results based on scenario (c) fit 373 better with the expected ages (Fig. 5c). However, the best results were obtained using the first sce374 nario (a), i.e. with meteoric ${ }^{10} \mathrm{Be}$ deposition rates dependent on the amount of precipitation.

375 Consequently, the deposition rates of ${ }^{10} \mathrm{Be}$ substantially influence the calculated age of the soils. 376 The relation between the error of ${ }^{10} \mathrm{Be}$ deposition rates and the derived age is non-linear (Fig. 6). 377 Relatively small errors have a substantial effect on the age calculations.

Soil erosion rates

380 Soil macromorphology as well as soil chemistry (see Tables 2, 3) did not give any evidence that the 381 soils were subjected to erosion. Some erosion, however, might have occurred which is only detect- 
382 able using a "tracer" such as ${ }^{10} \mathrm{Be}$. Over the past few years, the technique of cosmogenic nuclides 383 has been extended to determine long-term erosion rates on a catchment scale or on single soil pro384 files. For a recent summary of the technique and new applications see von Blanckenburg (2006) and 385 Schaller et al. (2009a). The nuclide concentration is inversely proportional to the catchment area 386 erosion rate and the soil erosion rate. The assumption of a steady state is often an essential prerequi387 site of this technique (Schaller and Ehlers, 2006). In addition, short-term erosion rates can be esti388 mated, for example, using ${ }^{137}$ Cs (Collins et al., 2001). Knowing the age of a landform and having 389 the calculated ${ }^{10} \mathrm{Be}$ age derived from soils, soil erosion can be estimated by comparing the effective 390 abundance of ${ }^{10} \mathrm{Be}$ measured in the soil with the theoretically necessary abundance for the expected 391 age. To evaluate a possible erosion of the soils, we assume that the material is eroded from the sur392 face at a constant rate $E$ (Maejima et al., 2005). Equation (3) can be extended to:

$$
t_{c o r r}=-\frac{1}{\lambda}\left(1-\lambda \frac{N}{q-\rho E m}\right)
$$

where $m$ is the measured concentration of ${ }^{10} \mathrm{Be}$ in the top eroding horizons (atoms/g), $\rho$ is the bulk density $\left(\mathrm{g} / \mathrm{cm}^{3}\right)$ of the top horizons and $t_{\text {corr }}$ the correct (expected) age. Erosion rates are obtained from the difference $\Delta t=t_{\text {corr }}-t$ (Equations 3 and 6) where the parameters $\Delta t$ and $t$ are known. Using the approach with meteoric ${ }^{10} \mathrm{Be}$ deposition rates that depend on the precipitation amount 400 (scenario a), the calculated erosion ranges lie within $<1-18.4 \mathrm{~mm} / \mathrm{ky}$ (Table 6). These values are 401 low but possible. Schaller et al. (2009b) determined erosion rates from moraine ridges in the order 402 of $8-23 \mathrm{~mm} / \mathrm{ky}$. Although a comparison between moraine and catchment-wide erosion is difficult, 403 it can give at least an indication about a possible range. Our calculated erosion rates are similar to 404 the results of Granger et al. (2001), where catchment erosion rates at Adams Peak and Antelope 405 Lake (north-eastern Sierra Nevada, CA, USA) were in the range between 15 and $60 \mathrm{~mm} / \mathrm{ky}$. 406 Schaller et al. (2001) measured $20-100 \mathrm{~mm} / \mathrm{ky}$ erosion rates for middle European river catch- 
ments. In these studies, an averaged erosion rate is obtained over a larger area. The investigated al408 pine soils, however, developed on stable surfaces and partially at almost flat positions. Vegetation 409 as well as the stony character of the sites render them much less susceptible to erosion. Boulders 410 also shield the underlying soil from erosion (Granger et al., 2001). A high soil skeleton content as 411 well as vegetation cover and roots prevent soils from erosion (Richter, 1998). No erosion rates can 412 be derived using the approach with a constant meteoric ${ }^{10} \mathrm{Be}$ influx (the ${ }^{10} \mathrm{Be}$ inventory in soils is in 413 this case $>$ expected inventory). Assuming a pre-exposure of the parent material and a constant ${ }^{10} \mathrm{Be}$ 414 influx, the calculated erosion rates lie between 1 and $57 \mathrm{~mm} / \mathrm{ky}$ (Table 6). Although the maximum 415 rates are rather high, the results are in a plausible range.

416 An additional approach to calculate erosion rates is the one proposed by Lal (2001) using:

$$
E=z_{0} K_{E}
$$

419 and:

$$
K_{E}=\frac{N_{D}}{N_{S}}\left[\frac{Q+q_{a}}{N_{D}}\right]-\lambda
$$

where $E=$ erosion rate, $z_{0}=$ thickness of topsoil horizons (comprising $\mathrm{O}$ and $\mathrm{A}$ horizon), $K_{E}=$ first order rate constant for removal of soil from the topsoil layer, $N_{D}={ }^{10}$ Be inventory in the D layer (= remainder of the soil profile comprising B and C horizons; atoms $\left./ \mathrm{cm}^{2}\right), N_{S}={ }^{10} \mathrm{Be}$ inventory in topsoil horizons (atoms $/ \mathrm{cm}^{2}$ ), $Q=$ flux of atmospheric ${ }^{10} \mathrm{Be}$ into the topsoil (atoms $\left./ \mathrm{cm}^{2} / \mathrm{y}\right), q_{a}=$ flux of accreted aeolian ${ }^{10} \mathrm{Be}\left(\right.$ atoms $\left./ \mathrm{cm}^{2} / \mathrm{y}\right)$.

426 To treat the limited data available for ${ }^{10} \mathrm{Be}$, the aeolian addition of ${ }^{10} \mathrm{Be}$ with dust is neglected al427 though it might be appreciable in some cases (Lal, 2001). Using the approach of Lal (2001), high 428 erosion rates were calculated that seem to be rather unrealistic. For the investigated soils, the ero429 sion rates would be $100 \mathrm{~mm} / \mathrm{ky}$ for Val di Rabbi, $45 \mathrm{~mm} / \mathrm{ky}$ for Schmadri profile 1, $82 \mathrm{~mm} / \mathrm{ky}$ for 430 Schmadri profile 2, $180 \mathrm{~mm} / \mathrm{ky}$ for Val Mulix, $95 \mathrm{~mm} / \mathrm{ky}$ for Meggerwald and $36 \mathrm{~mm} / \mathrm{ky}$ for 431 Morteratsch. Tsai et al. (2008) calculated an erosion rate in the order of $7-17 \mathrm{~mm} / \mathrm{ky}$ for soils of a 
terrace sequence with an age of about $100-400 \mathrm{ky}$ - values that correspond fairly well to our investigated soils. Using the calculated erosion rates according to Lal (2001), unrealistic soil ages were also obtained (using Equation 6): $66 \mathrm{ky}$ for the Schmadri profile 1. For all other soils the term $\left(\frac{N}{q-\rho E m}\right)$ in Equation 6 became negative and no age could be calculated.

A basic assumption of Lal (2001) is that the soils are in a steady-state condition — the B horizon, for instance, should not change its thickness — which is not valid for the rather young, alpine soils. Alpine soils have evolved over the last $20 \mathrm{ky}$ and soil thickness is still changing. Furthermore, the Lal-approach considers only an average soil density (using the same density for the topsoils as well as for the subsoil), which is also an excessively simplified approach.

In contrast to the "'open system'” assumptions used here, Lal et al. (1991) proposed a "'closed system" model for soil age determination, in which the ${ }^{10} \mathrm{Be} /{ }^{9} \mathrm{Be}$ ratio in authigenic soil minerals lock at the time of formation. Age calculations assume a closed system with a decrease of the ${ }^{10} \mathrm{Be} /{ }^{9} \mathrm{Be}$ ratio from the C- to the B-horizon. Barg et al. (1997) suggested that the ${ }^{10} \mathrm{Be} /{ }^{9} \mathrm{Be}$ ratios in authigenic phases can be used to obtain useful age models for soils younger than $10-15 \mathrm{My}$. ${ }^{10} \mathrm{Be} /{ }^{9} \mathrm{Be}$ ratio for soil mineral phases are, however, not available for our studied soils.

\section{Conclusions}

In this study we tried to derive surface ages using ${ }^{10} \mathrm{Be}$ in soils. We were able to compare the obtained ages with existing age determinations (radiocarbon, surface exposure dating). We obtained the following main findings:

- Meteoric ${ }^{10}$ Be has been involved in soil processes such as eluviation and illuviation (due to podzolisation). 
- Mass changes of ${ }^{10} \mathrm{Be}$ in the investigated soil profile (erosion, leaching and accumulation processes) may affect the determined age.

- The uncertainties using the ${ }^{10} \mathrm{Be}$ inventory in soils were substantial and varied in the range of $8-21 \%$, because analytical errors as well as errors from other parameters such as bulk soil density and soil skeleton content have to be taken into account. propriate estimation of meteoric ${ }^{10} \mathrm{Be}$ deposition rates. Uncertainties in the estimate of the ${ }^{10} \mathrm{Be}$ deposition rates substantially influence the derived age.

- The scenario in which meteoric ${ }^{10} \mathrm{Be}$ inputs to soils were used on the basis of annual precipitation rates and were compared to the ${ }^{10} \mathrm{Be}$ inventory in the soils produced a reasonably good fit with the ages obtained from SED or radiocarbon dating. The scenario having a constant atmospheric ${ }^{10} \mathrm{Be}$ flux failed to adequately predict the soil age and erosion rates. Assuming a pre-exposure of the soils to meteoric ${ }^{10} \mathrm{Be}$ flux provided better results compared with the scenario having only a constant meteoric ${ }^{10} \mathrm{Be}$ input.

- Similarly to surface exposure dating using ${ }^{10} \mathrm{Be}$, the problem of pre-exposure exists. At one of our investigated sites, a pre-exposure to meteoric ${ }^{10} \mathrm{Be}$ flux was most probably the cause for the too-high age measured.

- A relative age estimate and under optimal conditions a numerical dating using ${ }^{10} \mathrm{Be}$ in soils can be, nonetheless, carried out.

- ${ }^{10} \mathrm{Be}$ is a useful tracer for determining soil formation rates and erosion. A steady-state approach for young, alpine soils $(<25 \mathrm{ky})$ is, however, not suitable to estimate erosion rates. The whole soil system is not yet close to or not long enough close to a quasi-steady state.

- The atmospheric ${ }^{10} \mathrm{Be}$ approach gives another possibility for dating surfaces when other methods fail or are not possible at all. The dating of surfaces using ${ }^{10} \mathrm{Be}$ is, however, laborious and has strong limitations. Our results are based on 6 soil profiles. More investigations would be necessary to underpin our findings. 


\section{Acknowledgements}

We would like to express our appreciation to B. Kägi for his assistance in the laboratory. This study was supported by the Swiss National Science Foundation grant number 20-109565/1 and the

“Stiftung für wissenschaftliche Forschung an der Universität Zürich”. We are, furthermore, indebted to three unknown reviewers and the editor Andrew Plater for their helpful comments on an earlier version of the manuscript.

References

Barg, E., Lal, D., Pavich, M.J., Caffee, M.W., Southon, J.R., 1997. Beryllium geochemistry in soils: evaluation of ${ }^{10} \mathrm{Be} /{ }^{9} \mathrm{Be}$ ratios in authigenic minerals as a bais for age models. Chemical Geology $140,237-258$.

Belmaker, R., Lazar, B., Tepelyakov, N., Stein, M., Beer, J., 2008. ${ }^{10}$ Be in Lake Lisan sediments A proxy for production or climate?, Earth Planetary Science Letters 269, 447-456.

Böhlert, R., Egli, M., Maisch, M. Brandová, D., Ivy-Ochs, S., Kubik, P.W., Haeberli, W., submitted. Application of a combination of dating techniques to reconstruct the Lateglacial and early Holocene landscape history of the Albula region (eastern Switzerland).

Bronk Ramsey, C., 2001. Development of the radiocarbon calibration program OxCal. Radiocarbon 43, 355-363.

Brown, L., Stensland, G.J., Klein, J., Middleton, R., 1989. Atmospheric deposition of ${ }^{7}$ Be and ${ }^{10}$ Be. Geochimica et Cosmochimica Acta 53, 135-142.

Brown, E.T., Edmond, J.M., Raisbeck., G.M. Bourlès, D., Yiou, F., Measures., C. 1992. Beryllium isotope geochemistry in tropical river basins. Geochimica Cosmochimica Acta 56, 1607-1624.

Collins, A.L., Walling, D.E., Sichingabula, H.M., Leeks, G.J.L., 2001. Using ${ }^{137}$ Cs measurements 
to quantify soil erosion and redistribution rates for areas under different land use in the Upper 509 Kaleya River basin, southern Zambia. Geoderma 104, 299-323.

510 Desaules, A., Dahinden, R. 2000. Nationales Bodenbeobachtungsnetz. Veränderungen von 511 Schadstoffgehalten nach 5 und 10 Jahren. Bundesamt für Umwelt, Wald und Landschaft (BU512 WAL), Schriftenreihe Umwelt Nr. 320, Bern

513 EDI (Eidgenössisches Departement des Innern), 1992. Hydrologischer Atlas der Schweiz. Lande$514 \quad$ shydrologie und -geologie, Bern, Switzerland.

515 Egli, M., Sartori, G., Mirabella, A., Favilli, F. 2009. Effect of north and south exposure on organic 516 matter in high Alpine soils. Geoderma, 149, 124-136.

517 Egli, M., Mirabella, A., Fitze, P., 2003. Formation rates of smectites derived from two Holocene 518 chronosequences in the Swiss Alps. Geoderma, 117, 81-98.

519 Egli, M., Zanelli, R., Kahr, G., Mirabella, A., Fitze, P., 2002. Soil evolution and development of the 520 clay mineral assemblage of a Podzol and Cambisol in "Meggerwald" (Switzerland). Clay Minerals 37, 351-366.

Egli, M., Mirabella, A. 2001. Bodenkundliche Untersuchungen im spät- und postglazialen Bereich des Hinteren Lauterbrunnentals (Berner Oberland, Schweiz): Bodenchemischer und mineralogischer Vergleich zweier Podsole auf unterschiedlich alten Moränen. Geographica Helvetica $56,117-132$.

Favilli, F., Egli, M., Brandová, D., Ivy-Ochs, S., Kubik, P.W., Cherubini, P., Mirabella, A., Sartori, G., Giaccai, D., Haeberli, W. 2009. Combined use of relative and absolute dating techniques for detecting signals of Alpine landscape evolution during the late Pleistocene and early Holocene. 530 Favilli, F., Cherubini, P., Collenberg, M., Egli, M., Sartori, G., Schoch, W., Haeberli, W., 2010. 531 Charcoal fragments of Alpine soils as an indicator of landscape evolution during the Holocene in Val di Sole (Trentino, Italy). The Holocene 20, 1-13.

533 Field, C.V., Schmidt, G.A., Koch, D., Salyk, C., 2006, Modeling production and climaterelated im- 
pacts on ${ }^{10} \mathrm{Be}$ concentration in ice cores. Journal of Geophysical Research 111 (D15107) doi:10.1029/2005JD006410.

Fitze, P.F., 1982. Zur Relativdatierung von Moränen aus der Sicht der Bodenentwicklung in den kristallinen Zentralalpen. Catena 9, 265 - 306.

Florineth, D., 1998. Surface geometry of the Last Glacial Maximum (LGM) in the southeastern Swiss Alps (Graubünden) ant its paleoclimatic significance. Eiszeitalter und Gegenwart 48, 23 37.

Gosse, J.C,, Phillips, F.M., 2001. Terrestrial in situ produced cosmogenic nuclides: Theory and application. Quaternary Science Reviews 20, 1475-1560.

Gosse, J.C., Klein, J., Evenson, E.B., Lawn, B., Middleton, R., 1995. Beryllium-10 dating of the duration and retreat of the last Pinedale glacial sequence. Science 268, 1329-1333.

Graham, I., Ditchburn, R., Barry, B., 2003. Atmospheric deposition of ${ }^{7}$ Be and ${ }^{10}$ Be in New Zealand rain (1996-98). Geochimica et Cosmochimica Acta 67, 361-373.

Granger, D.E., Clifford, S.R., Kirchner, J.W., Finkel, R.C., 2001. Modulation of erosion on steep granitic slopes by boulder armouring, as revealed by cosmogenic ${ }^{26} \mathrm{Al}$ and ${ }^{10} \mathrm{Be}$. Earth and Planetary Science Letters 186, 269-281.

Hantke, R., 1983. Eiszeitalter 3: Die jüngste Erdgeschichte der Schweiz und ihrer Nachbargebiete. 556 Heikkilä, U., Beer, J., Alfimov, V. 2008b. Beryllium-10 and Beryllium-7 in precipitation in Dübendorf (440 m) and at Jungfraujoch (3580 m), Switzerland (1998-2005). Journal of Geophysical Research 113: D11104, doi: 10.1029/2007JD009160.

Heikkilä, U. 2007. Modeling of the atmospheric transport of the cosmogenic radionuclides 10Be 
and 7Be using the ECHAM5-HAM General Circulation Model. Ph.D. thesis. ETHZurich. 148 $561 \quad \mathrm{pp}$.

562 Hitz, C., Egli, M., Fitze, P., 2002. Determination of the sampling volume for representative analysis 563 of alpine soils. Zeitschrift für Pflanzenernährung und Bodenkunde 165, 326-331.

564 Holzhauser, H. 1984. Zur Geschichte der Aletschgletscher und des Fieschhergletschers. PhD thesis, $565 \quad$ University of Zürich, Switzerland.

566 Horiuchi, K., Minoura, K., Kobayashi, K., Nakamura, T., Hatori, S., Matsuzaki, H., Kawai, T., 1999. Last-glacial to post-glacial ${ }^{10} \mathrm{Be}$ fluctuations in a sediment core from the Academician Ridge, Lake Baikal. Geophysical Research Letters 26, 1047-1050.

IUSS Working Group WRB. World Reference Base for Soil Resources 2006, $2^{\text {nd }}$ edition, World Soil Resources Reports No. 103, FAO (Food and Agriculture Organisation of the United Nations), Rome, 2006.

Ivy-Ochs, S., Kerschner, H., Maisch, M., Christl, M., Kubik, P.W., Schlüchter, C., 2009. Latest Pleistocene and Holocene glacier variations in the European Alps. Quaternary Science Reviews. Doi:10.1016/j.quascirev.2009.03.009

Ivy-Ochs, S., Kerschner, H., Reuther, A., Preusser, F., Heine, K., Maisch, M., Kubik, P.W., Schlüchter, C., 2008. Chronology of the last glacial cycle in the European Alps. Journal of Quaternary Science 23, 559-573.

Ivy-Ochs, S., Kerschner, H., Schlüchter, C., 2007. Cosmogenic nuclides and the dating of

Ivy-Ochs, S., Kerschner, H., Reuther, A., Maisch, M., Sailer, R., Schaefer, J., Kubik, P.W., Synal, H.A., Schlüchter, C., 2006a. The timing of glacier advances in the northern European Alps based on surface exposure dating with cosmogenic ${ }^{10} \mathrm{Be},{ }^{26} \mathrm{Al},{ }^{36} \mathrm{C}$ and ${ }^{21} \mathrm{Ne}$. In: Siame, L.L., Bourlès, D.L., Brown, T.T. (eds), In Situ-Produced Cosmogenic Nuclides and Quantification of Gelogical 
Processes. Geological Society of America; Geological Society of America Special Paper 415, pp. $43-60$.

Ivy-Ochs, S., Kerschner, H., Kubik, P.W., Schlüchter, C., 2006b. Glacier response in the European Alps to Heinrich Event 1 cooling: the Gschnitz stadial. Journal of Quaternary Science 21, 115130.

Ivy-Ochs, S., Schäfer, J., Kubik, P.W., Synal, H.A., Schlüchter, C., 2004. The timing of 591 deglaciation on the northern Alpine foreland (Switzerland). Eclogae Geologicae Helvetiae 97, 47-55.

Ivy-Ochs, S., Schlüchter, C, Kubik, P.W., Synal, H.-A., Beer, J., Kerschner, H., 1996. The exposure age of an Egesen moraine at Julier Pass measured with ${ }^{10} \mathrm{Be},{ }^{26} \mathrm{Al}$ and ${ }^{36} \mathrm{Cl}$. Eclogae Geologicae Helvetiae 89, 1049-1063.

Ivy-Ochs, S., Kober, F., 2008. Surface exposure dating with cosmogenic nuclides. Eiszeitalter und Gegenwart 57, 157-189.

Keller, O., 1988. Ältere spätwürmzeitliche Gletschervorstösse und Zerfall des Eisstromnetzes in den nördlichen Rhein-Alpen (Weissbad-Stadium/Bähl-Stadium). Physische Geographie 27, Zürich.

Keller, O., Krayss, E., 2005. Der Rhein-Linth -Gletscher im Hochglazial. 1. Teil: Einleitung; Aufbau und Abschmelzen des Rhein-Linth-Gletscher im Oberen Würm. Vierteljahresschrift der Naturforschenden Gesellschaft Zürich 150, 19-32.

Keller, O., Krayss, E., 1993. The Rhine-Linth Glacier in the upper Würm: A model of the last Alpine glaciation. Quaternary International 18, 15-27.

Kerschner, H., Ivy-Ochs, S., Schlüchter, C., 1999. Paleoclimatic interpretation of the early lateglacial glacier in the Gschnitz valley, central Alps, Austria. Annals of Glaciology 28, 135-140.

Kubik, P.W., Christl, C., 2009. ${ }^{10} \mathrm{Be}$ and ${ }^{26} \mathrm{Al}$ measurements at the Zurich 6 MV Tandem AMS facility. Nuclear Instruments and Methods B, doi: 10.1016/j.nimb.2009.10.054 
610 Lal, D., 2001. New nuclear methods for studies of soil dynamics utilizing cosmic ray produced for 611 raionuclides. In: Stott, D.E., Mohtar, R.H., Steinhardt, G.C. (eds.), Sustaining the Global Farm. $61210^{\text {th }}$ International Soil Conservation Organization Meeting, Purdue University and USDA-ARS 613 National Soil Erosion Research Laboratory, pp. 1044-1052.

614 Lal, D., 1988. In situ-produced cosmogenic isotopes in terrestrial rocks. Annual Review of Earth 615 and Planetary Sciences 16, 355-388.

616 Leidlmair A., 1996. Tirol-Atlas. Eine Landeskunde in Karten,Tiroler Landesregierung - Kultur617 referat, Alpina Offset, Innsbruck.

618 Ljung, K., Björck, S, Muscheler, R., Beer, J., Kubik, P.W., 2007. Variable ${ }^{10}$ Be fluxes in lacustrine 619 sediments from Tristan de Cunha, South Atlantic: a solar record? Quaternary Science Reviews $620 \quad 26,829-835$.

621 Maejima, Y., Matsuzaki, H., Higashi, T., 2005. Application of cosmogenic ${ }^{10} \mathrm{Be}$ to dating soils on 622 the raised coral reef terraces of Kikai Island, southwest Japan. Geoderma 126, 389-399.

623 Maejima, Y., Matsuzaki, H., Nakano, C., 2004. ${ }^{10}$ Be concentrations of red soils in Southwest Japan 624 and its possibility of dating. Nuclear Instruments and Methods in Physics Research B 223-224, $625 \quad 596-600$.

626 Maisch, M., 2000. The longterm signal of climate change in the Swiss Alps: glacier retreat since the 627 end of the little ice age and future decay scenarios. Geografia Fisica e Dinamica Quaternaria 23, $628 \quad 139-151$.

629 Maisch M. 1981. Glazialmorphologische und gletschergeschichtliche Untersuchungen im Gebiet 630 zwischen Landwasser- und Albulatal (Kt. Graubünden, Schweiz). PhD thesis, University of 631 Zurich, Switzerland.

632 Maisch, M., Brandova, D., Ivy-Ochs, S., Kubik, P.W., 2005. Exposure dating on moraines of the 633 Morteratsch glacier (Bernina region, Upper Engadine, GR). In: Haeberli, W., Giardini, D. (eds.), 634 Proceedings of the $3^{\text {rd }}$ Swiss Geoscience Meeting, Zürich, pp. 181-182.

635 Masarik, J., Beer, J. 1999. Simulation of particle fluxes and cosmogenic nuclide production in the 
Earth's atmosphere. Journal of Geophysical Research 104, 12099-12111.

McKeague, J.A., Brydon, J.E., Miles, N.M., 1971. Differentiation of forms of extractable iron and aluminium in soils. Soil Science Society of America Proceeding 35, 33-38.

Monaghan, M.C., Krishnaswami, S., Turekian, K.K., 1985/1986. The global average production of ${ }^{10}$ Be. Earth Planetary Science Letters 76, 279-287.

Monaghan, M.C., Krishnaswami, S., Thomas, J.H., 1983. ${ }^{10}$ Be concentrations and the long-term 642 fate of particle-reactive nuclides in five soil profiles from California. Earth and Planetary

644 Morris, J.D., 1991. Applications of cosmogenic ${ }^{10} \mathrm{Be}$ to problems in earth sciences. Annual Reviews of Earth Science 19, 113-150.

Pavich, M.J., Brown, L., Valette-Silver, J.N., Klein, J., Middleton, R., 1985. ${ }^{10}$ Be analysis of a Quaternary weathering profile in the Virginia Piedmont. Geology 13, 39-41.

Pavich, M.J., Brown, L., Klein, J., Middleton, R., $1984 .{ }^{10}$ Be accumulation in a soil chronosequence. Earth and Planetary Science Letters 68, 198-204.

Pavich, J.M., Vidic, N. 1993. Application of paleomagnetic and ${ }^{10}$ Be analyses to chronostratigraphy of Alpine glaciofluvial terraces, Sava River Valley, Slovenia. In: Swart, P. (Ed.), Climate Change in Continental Isotopic Records. Geophysical Monographs 78, 263-275.

Penck, A., Brückner, E., 1909. Die Alpen im Eiszeitalter. 3 volumes, Leipzig, Tauchnitz.

Raisbeck, E., Yiou, F., Fruneau, M., Loiseaux, J.M., Lieuvin, M., Ravel, J.C., 1979. Deposition rate and seasonal variations in precipitation of cosmogenic ${ }^{10} \mathrm{Be}$. Nature 282, 279-280.

Reimer P.J., Baillie M.G.L., Bard E., Bayliss A., Beck J.W., Bertrand C.J.H., Blackwell P.G., Buck C.E., Burr G.S., Cutler K.B., Damon P.E., Edwards R.L., Fairbanks R.G., Friedrich M., Guilderson T.P., Hogg A.G., Hughen K.A., Kromer B., McCormac G., Manning S., Bronk Ramsey C., Reimer R.W., Remmele S., Southon J.R., Stuiver M., Talamo S., Taylor F.W., van der Plicht J., Weyhenmeyer C.E., 2004. IntCal04 terrestrial radiocarbon age calibration, 0-26 cal kyr BP. Radiocarbon 46, 1029-1058. 
662 Reuther, A.U., Ivy-Ochs, S,, Heine, K., 2006. Application of surface exposure dating in glacial 663 geomorphology and the interpretation of moraine ages. Annals of Geomorphology 142, 335-359. 664 Richter, G. (Ed.) 1998. Bodenerosion. Analyse und Bilanz eines Umweltproblems. Wissen665 schaftliche Buchgesellschaft, Darmstadt.

666 Sachs, L., 1992. Angewandte Statistik. Anwendung statistischer Methoden. Siebte Auflage, 667 Springer-Verlag, Berlin.

668 Schaller, M., Ehlers, T. A., 2006. Limits to quantifying climate driven changes in denudation rates 669 with cosmogenic radionuclides. Earth and Planetary Science Letters, 248, 138-152.

670 Schaller, M., T., Ehlers, A., Blum, J. D., Kallenberg, M. A., 2009a. Quantifying glacial moraine 671 age, denudation, and soil mixing with cosmogenic nuclide depth profiles, Journal of Geophysical $672 \quad$ Research, 114, F01012, doi:10.1029/2007JF000921.

673 Schaller, M., Blum, J. D., T., Ehlers, A., 2009b. Combining cosmogenic nuclides and major ele674 ments from moraine soil profiles to improve weathering rate estimates. Geomorphology 106, $675 \quad 198-205$.

676 Schaller, M., von Blanckenburg, F., Hovius, N., Kubik, P.W., 2001. Large-scale erosion rates from 677 in situ-produced cosmogenic nuclides in European river sediments. Earth and Planetary Science $678 \quad$ Letters $188,441-458$.

679 Schlüchter, C., 2004. The Swiss glacial record - A schematic summary. In: Ehlers, J., Gibbard, P.L. 680 (eds), Quaternary Glaciations- Extent and chronology, Part I: Europe. Elsevier, London, pp. 413$681 \quad 418$.

682 Schoeneich, P., 1999. Le retrait glaciaire dans les vallées des Ormonts, de l'Hongrin et de l'Etivaz 683 (Préalpes vaudoises). Thèse de la Faculté des lettres de l'Université de Lausanne, Travaux et re$684 \quad$ cherche, 14, Vol. $1 \& 2$.

685 Schwarb, M., Daly, C., Frei, C., Schär, C., 2000. Mittlere jährliche Niederschlagshöhe im 686 europäischen Alpenraum 1971-1990. Hydrologischer Atlas der Schweiz, Blatt 2.6., Bern. 
687 Tsai, H., Maejima, Y., Hseu, Z.-Y., 2008. Meteoric ${ }^{10}$ Be dating of highly weathered soils from 688 fluvial terraces in Taiwan. Quaternary International 188, 185-196.

689 van Husen, D., 2004. Quaternary glaciations in Austria In: Ehlers, J., Gibbard, P.L. (eds), 690 Quaternary Glaciations- Extent and chronology, Part I: Europe. Elsevier, London, pp. 1-13.

691 von Blanckenburg, F., 2006. The control mechanisms of erosion and weathering at basin scale from 692 cosmogenic nuclides in river sediment. Earth and Planetary Science Letters 242, 224-239.

693 Vonmoos, M., Beer, J., Muscheler, R. 2006. Large variations in Holocene solar activity: Constraints 694 from ${ }^{10} \mathrm{Be}$ in the Greenland Ice Core Project ice core. Journal of Geophysical Research 111: 695 A10105 doi:10.1029/2005JA011500.

696 Willenbring, J. K., von Blanckenburg, F., 2009. Meteoric cosmogenic Beryllium-10 adsorbed to 697 river sediment and soil: Applications for Earthsurface dynamics, Earth Science Reviews, doi: $698 \quad$ 10.1016/j.earscirev.2009.10.008

699 Wipf, A., 2001. Gletschergeschichtliche Untersuchungen im spät- und postglazialen Bereich des $700 \quad$ Hinteren Lauterbrunnentals (Berner Oberland, Schweiz). Geographica Helvetica 56, 133-144.

701 Zanelli, R., 2002. Podsolverbreitung im Meggerwald: geochemische und tonmineralogische Unter702 suchungen. Diploma thesis, Department of Geography, University of Zürich, Switzerland.

703 Zhou, W., Priller, A., Beck, J.W., Zhengkun, W., Maobai, C., Zhisheng, A., Kutschera, W., Feng, 704 X., Huagui, Y., Lin, L., 2007. Disentangling geomagnetic and precipitation signals in an 80-kyr 705 Chinese loess record of ${ }^{10} \mathrm{Be}$. Radiocarbon 49, 139-160.

706 Zwahlen, P., 2008. Geologische Karte des Quartärs im Prättigau (Graubünden, Schweiz). 707 Geographica Helvetica 63, 193-205. 
Figure captions

Fig. 1. Impression of the investigation sites with the main geomorphic features (moraines) and sampling sites. $\mathrm{LGM}=$ Lateglacial maximum; 1850 and 1857 moraines correspond to the Little Ice Age. A: Val di Rabbi; B: Morteratsch (air photo from C. Rothenbühler), C: Schmadri with C1 with a detailed picture of the Holocene-aged and 1850 moraines (Wipf, 2001). The Younger Dryas moraine is curtly outside the photo; C2: Overview Schmadri and glacier stages (Google Earth), D: Val Mulix, E: Meggerwald (photo taken from wandersite; http://www.wandersite.ch; Ursula Brem).

Fig. 2. Profile photos of the investigated soils. A) Val di Rabbi; B) Morteratsch (photo: P. Fitze); C) Schmadri, profile 1; D) Schmadri profile 2; E) Val Mulix; F) Meggerwald (Photo: M. Achermann).

Fig. 3. Depth profiles (with horizon depth and designation) showing the accumulated meteoric ${ }^{10} \mathrm{Be}$ in the soils.

Fig. 4. Correlation between measured ${ }^{10} \mathrm{Be}$ deposition rates (data from Brown et al., 1992; Graham et al., 2003; Maejima et al., 2005; Vonmoos et al., 2006; Ljung et al., 2007; Zhou et al., 2007; Belmaker et al., 2008; Heikkilä et al., 2008b) and modelled fluxes (according to Field et al., 2006; Heikkilä et al., 2007; Willenbring and von Blanckenburg, 2009).

Fig. 5. Correlation between ${ }^{10} \mathrm{Be}$ ages (and uncertainty range) derived from soil analyses and expected surface age (reference surface age; derived either from surface exposure dating or from radiocarbon analyses; see also Table 4); a) using ${ }^{10} \mathrm{Be}$ deposition rates as a function of 
the annual amount of precipitation, b) constant ${ }^{10} \mathrm{Be}$ deposition fluxes for the Central Alps, c) like b) and assuming a background ${ }^{10} \mathrm{Be}$ level in the parent material.

Fig. 6. Effect of errors of ${ }^{10} \mathrm{Be}$ deposition rates estimation (error propagation) on the calculated surface age. 


\section{Click here to download high resolution image}
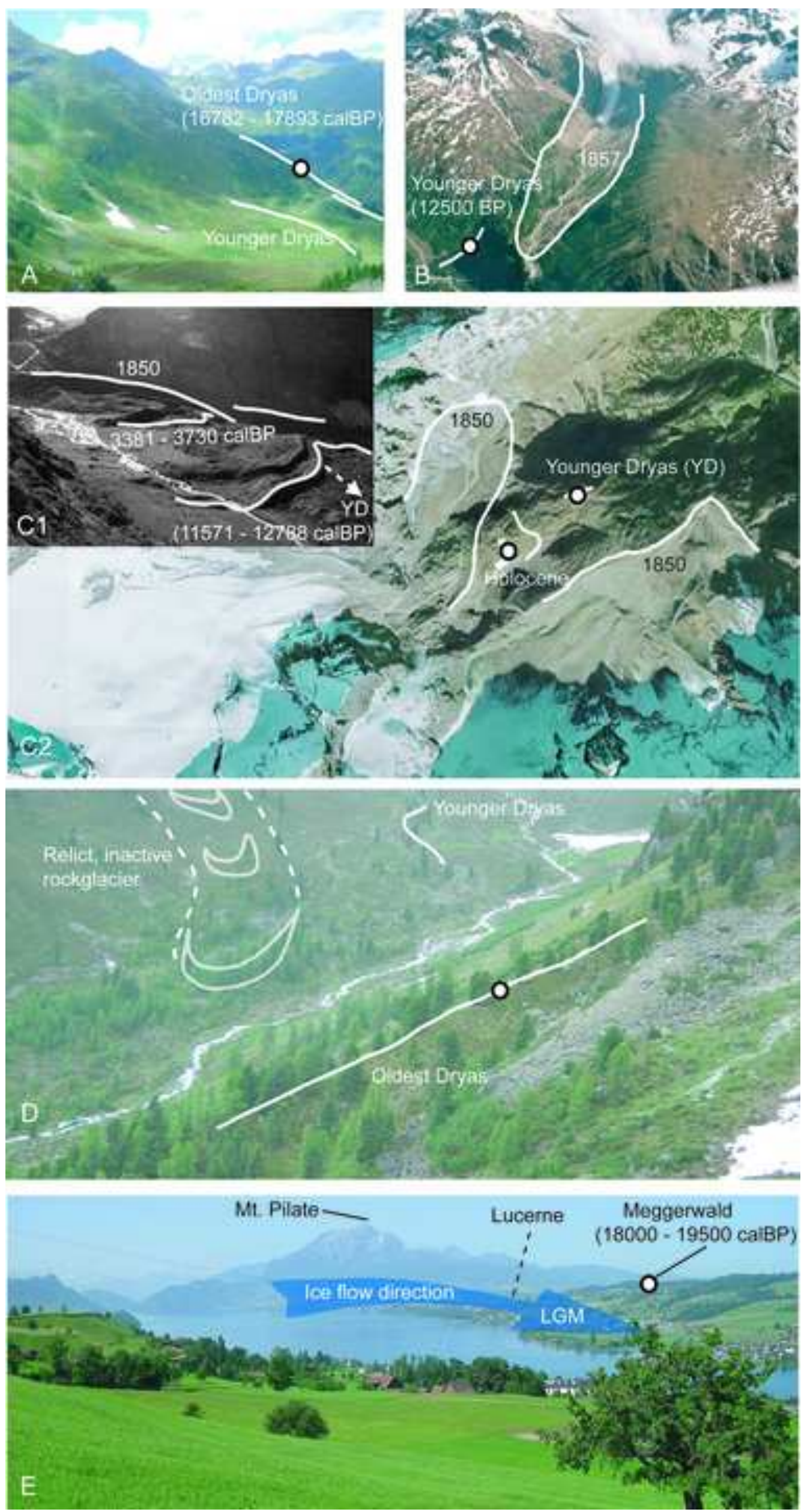
Click here to download high resolution image
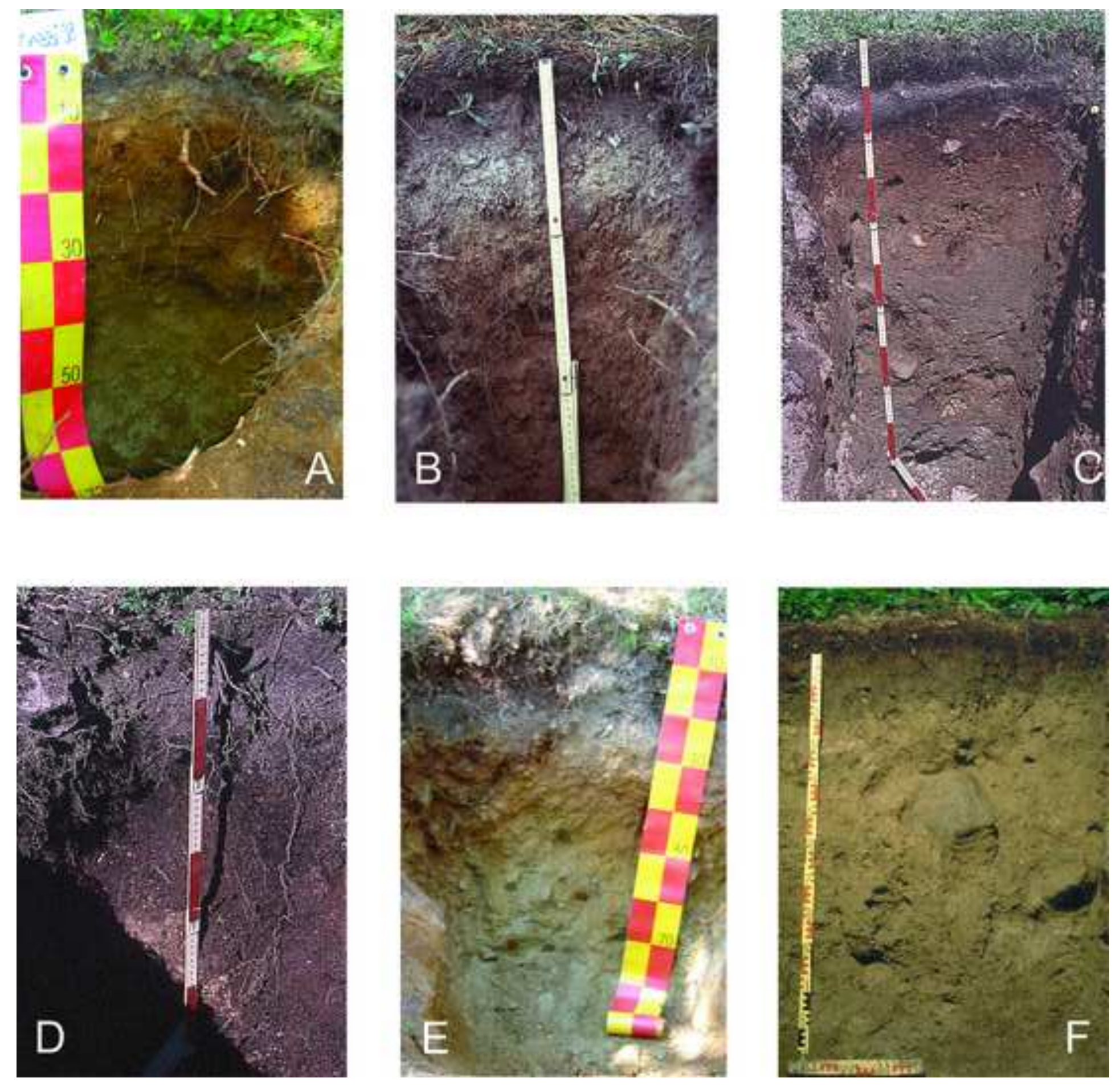

Figure 2 

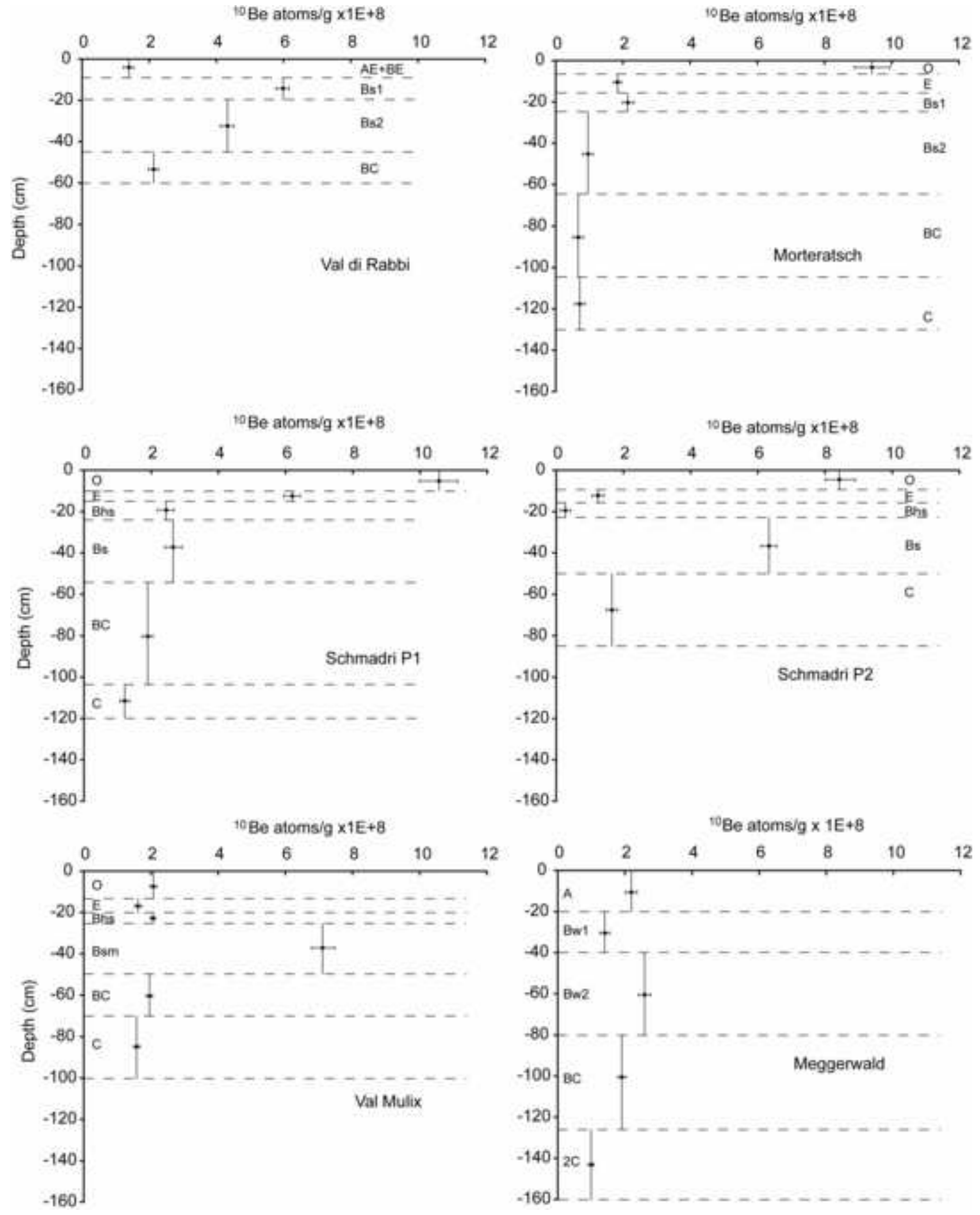


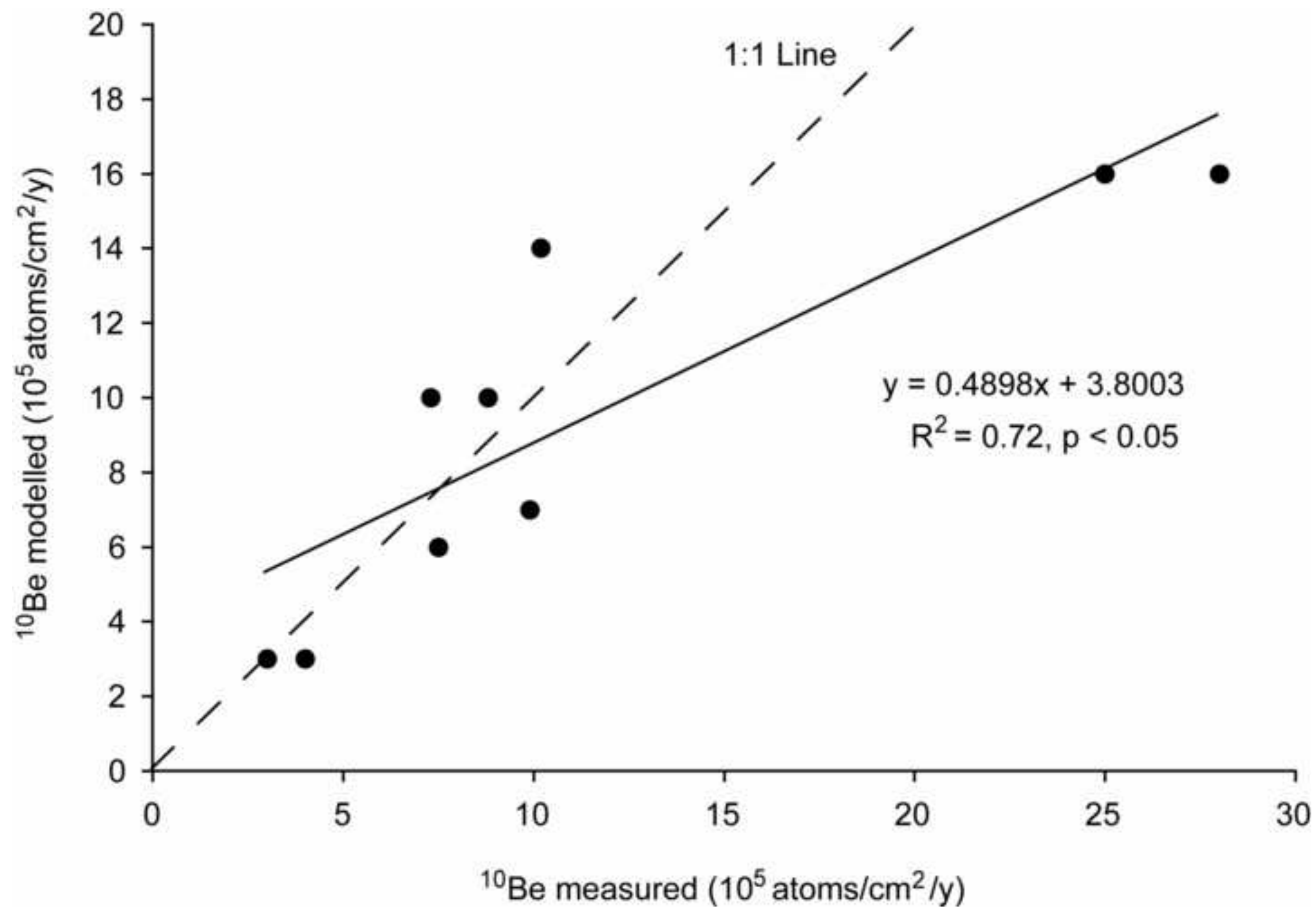




\section{Click here to download high resolution image}

a)

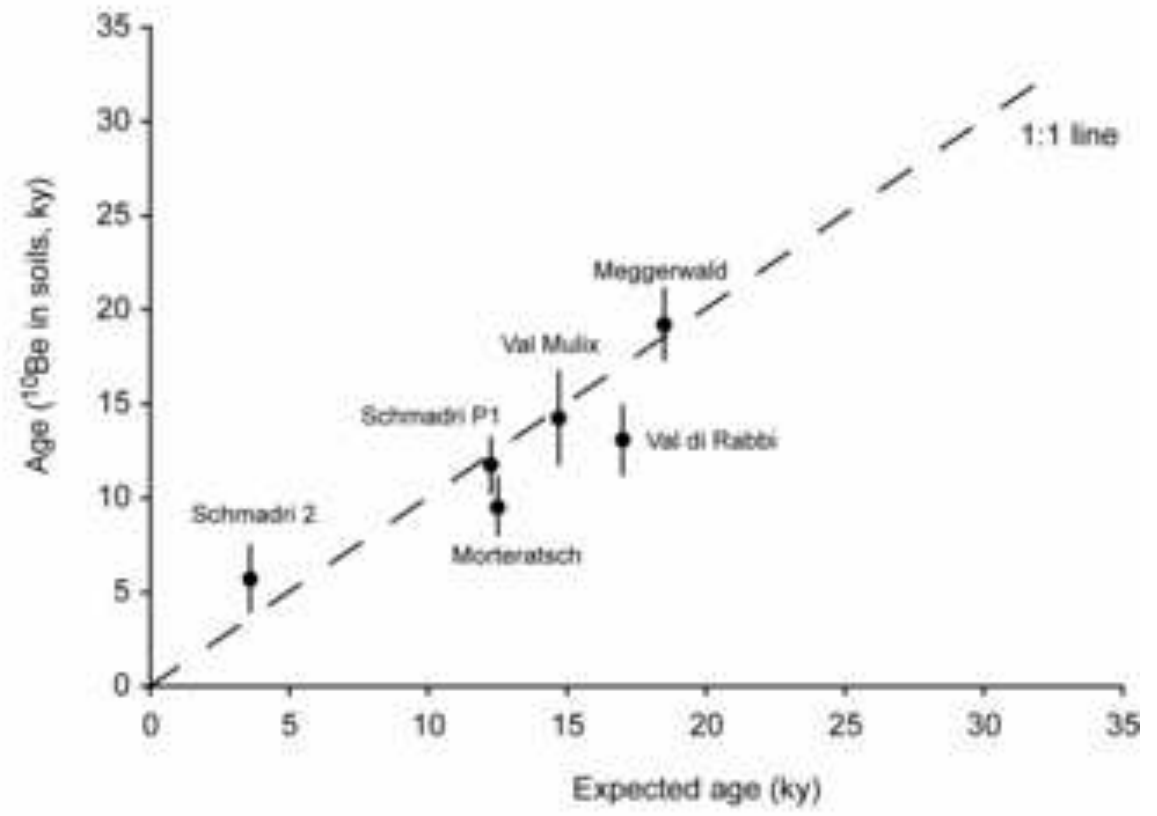

b)

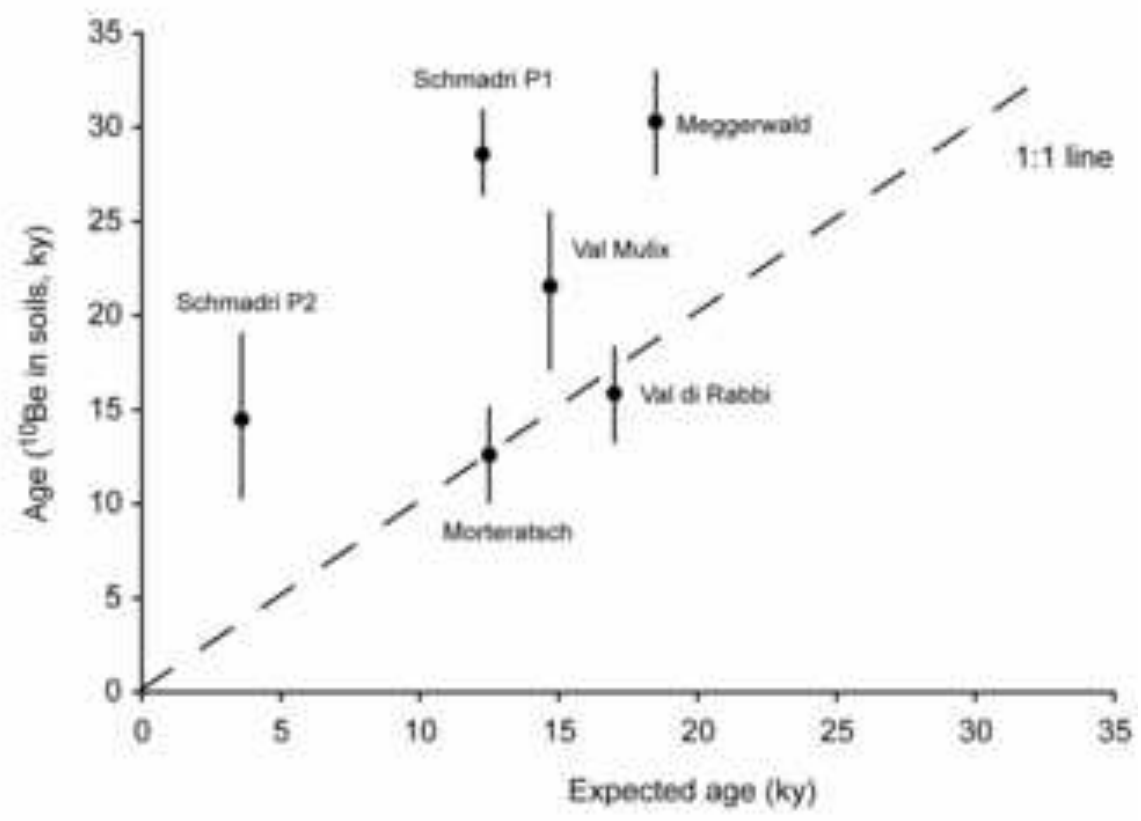

c)

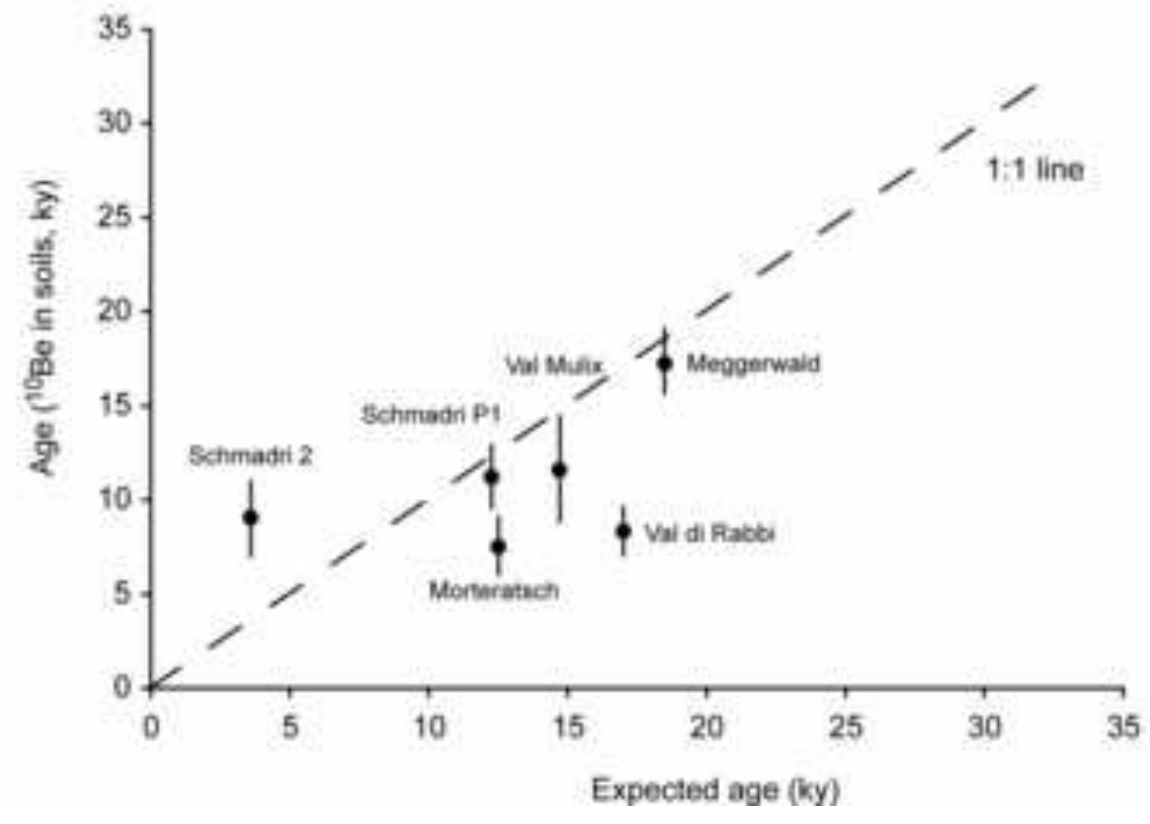




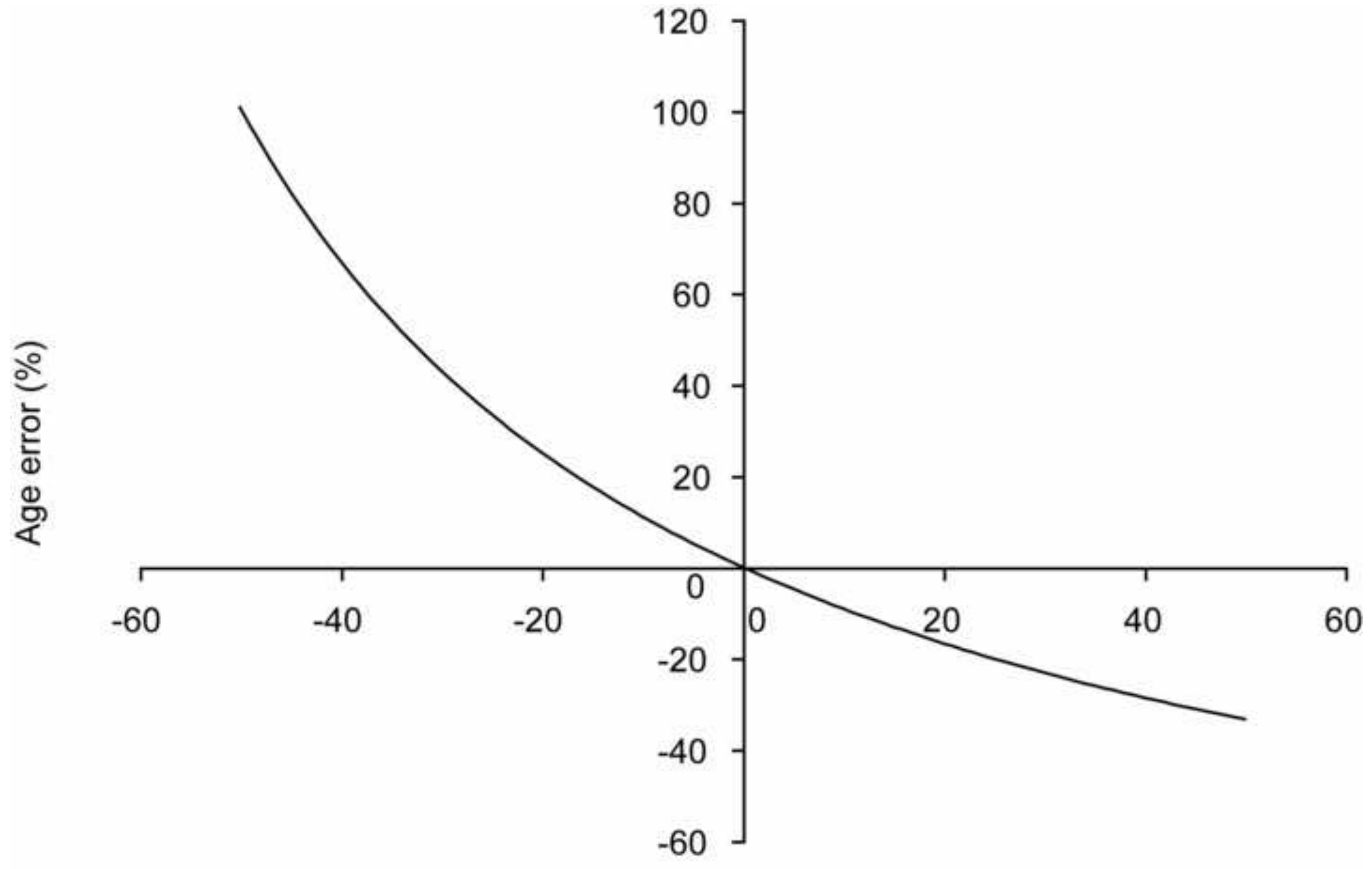

${ }^{10} \mathrm{Be}$-deposition rate error (\%) 
Table 1

Characteristics of the study sites

\begin{tabular}{|c|c|c|c|c|c|c|c|c|c|c|c|c|}
\hline Site & $\begin{array}{c}\text { Coordinates }^{1} \\
(\mathrm{~N} / \mathrm{E})\end{array}$ & $\begin{array}{c}\text { Elevation } \\
\text { (m asl) }\end{array}$ & $\begin{array}{c}\text { Dip } \\
\text { direction } \\
\left({ }^{\circ} \mathrm{N}\right)\end{array}$ & $\begin{array}{c}\text { Slope } \\
(\%)\end{array}$ & $\begin{array}{c}\mathrm{MAAT}^{2} \\
\left({ }^{\circ} \mathrm{C}\right)\end{array}$ & $\begin{array}{l}\mathrm{MAP}^{2} \\
(\mathrm{~mm} / \mathrm{y})\end{array}$ & Parent material & Location & $\begin{array}{c}\text { Late- and } \\
\text { postglacial } \\
\text { chronozone }\end{array}$ & Vegetation & Land use & $\begin{array}{c}\text { WRB } \\
\text { (IUSS Working } \\
\text { Group 2006) }\end{array}$ \\
\hline Val di Rabbi & $\begin{array}{c}46^{\circ} 22^{\prime} / \\
10^{\circ} 45^{\prime}\end{array}$ & 2100 & 60 & 32 & 1.8 & 1100 & $\begin{array}{l}\text { Paragneiss rich } \\
\text { till }\end{array}$ & $\begin{array}{c}\text { Lateral } \\
\text { moraine }\end{array}$ & Oldest Dryas & $\begin{array}{c}\text { Larix decidua / } \\
\text { Juniperus } \\
\text { communis }\end{array}$ & $\begin{array}{c}\text { Natural } \\
\text { forest }\end{array}$ & Entic Podzol \\
\hline Morteratsch & $\begin{array}{c}46^{\circ} 26^{\prime} / \\
9^{\circ} 57^{\prime}\end{array}$ & 1980 & 350 & 10 & 0.5 & 1100 & Granite rich till & $\begin{array}{c}\text { Lateral } \\
\text { moraine }\end{array}$ & Egesen & Larici-Piceetum & $\begin{array}{c}\text { Natural } \\
\text { forest }\end{array}$ & Haplic Podzol \\
\hline $\begin{array}{l}\text { Schmadri, } \\
\text { profile } 1\end{array}$ & $\begin{array}{c}46^{\circ} 34^{\prime} / \\
8^{\circ} 21^{\prime}\end{array}$ & 2035 & 350 & $<5$ & 0.5 & 2000 & Granite rich till & $\begin{array}{c}\text { Lateral } \\
\text { moraine }\end{array}$ & Egesen & Festucetum & $\begin{array}{c}\text { Natural } \\
\text { grassland }\end{array}$ & Albic Podzol \\
\hline $\begin{array}{l}\text { Schmadri, } \\
\text { profile } 2\end{array}$ & $\begin{array}{c}46^{\circ} 34^{\prime} / \\
8^{\circ} 20^{\prime}\end{array}$ & 2065 & 20 & $<5$ & 0.5 & 2000 & Granite rich till & End moraine & Holocene & Festucetum & $\begin{array}{c}\text { Natural } \\
\text { grassland }\end{array}$ & Entic Podzol \\
\hline Val Mulix & $\begin{array}{c}46^{\circ} 34^{\prime} / \\
9^{\circ} 45^{\prime}\end{array}$ & 2100 & 35 & 19 & -1.1 & 1250 & Granite rich till & $\begin{array}{c}\text { Lateral } \\
\text { moraine }\end{array}$ & Oldest Dryas & Larici-Piceetum & $\begin{array}{c}\text { Natural } \\
\text { forest }\end{array}$ & Albic Podzol \\
\hline Meggerwald & $\begin{array}{c}47^{\circ} 04^{\prime} / \\
8^{\circ} 22^{\prime}\end{array}$ & 614 & 325 & $<10$ & 8.1 & 1300 & Granite rich till & $\begin{array}{l}\text { Ground } \\
\text { moraine }\end{array}$ & $\begin{array}{c}\text { LGM - } \\
\text { Oldest Dryas }\end{array}$ & $\begin{array}{c}\text { Dryopterido- } \\
\text { Abietetum } \\
\text { (Myrtillo- } \\
\text { Abietetum) }\end{array}$ & $\begin{array}{c}\text { Managed } \\
\text { forest }\end{array}$ & $\begin{array}{c}\text { Dystric } \\
\text { Cambisol }\end{array}$ \\
\hline
\end{tabular}

${ }^{1}$ World geodetic system (WGS84)

${ }^{2}$ MAAT $=$ mean annual air temperature, MAP = mean annual precipitation (according to Leidlmair, 1996; EDI, 1992; Schwarb et al., 2000). 
Table 2

Physical and morphological characteristics of the soils (Favilli et al., 2009; Egli et al., 2009; Egli and Mirabella, 2001; Egli et al., 2003; Böhlert et al., submitted).

\begin{tabular}{|c|c|c|c|c|c|c|c|c|}
\hline Site/profile & Soil & Depth & $\begin{array}{l}\text { Munsell } \\
\text { colour }\end{array}$ & Skeleton & $\begin{array}{l}\text { Bulk } \\
\text { density }\end{array}$ & Sand & Silt & Clay \\
\hline \multirow{6}{*}{ Val di Rabbi } & & & & & & & & \\
\hline & $\mathrm{AE}$ & $0-4$ & $10 Y R 3 / 3$ & 5 & 0.91 & 46 & 28 & 26 \\
\hline & $\mathrm{BE}$ & $4-8$ & $5 Y R$ 4/4 & 11 & 0.91 & 52 & 28 & 20 \\
\hline & Bs1 & $8-20$ & $7.5 Y R 4 / 4$ & 51 & 0.74 & 58 & 29 & 14 \\
\hline & Bs2 & $20-45$ & 10YR 4/4 & 45 & 1.16 & 67 & 28 & 5 \\
\hline & $\mathrm{BC}$ & $45-60$ & $10 Y R$ 5/4 & 34 & 1.41 & n.d. & n.d. & n.d. \\
\hline
\end{tabular}

Morteratsch

$\begin{array}{cccccrrc}\text { O } & 0-5 & 7.5 \text { YR 3/1 } & 14 & 0.80 & \text { n.d. } & \text { n.d. } & \text { n.d. } \\ \text { E } & 5-15 & 7.5 \text { YR 4/3 } & 30 & 1.34 & 54 & 38 & 8 \\ \text { Bs1 } & 15-25 & 7.5 \text { Y 4/4 } & 55 & 1.54 & 79 & 18 & 3 \\ \text { Bs2 } & 25-65 & \text { 10YR 4/6 } & 57 & 1.67 & \text { n.d. } & \text { n.d. } & \text { n.d. } \\ \text { BC } & 65-105 & \text { 10YR 6/4 } & 53 & 1.71 & 78 & 19 & 3 \\ \text { C } & 105-130 & \text { 10YR 6/3 } & 67 & 1.74 & 78 & 19 & 3\end{array}$

\section{Schmadri}

Profile 1

$\begin{array}{ccclcrrc}\text { O } & 0-10 & \text { 10YR 2/1 } & 0 & 0.39 & \text { n.d. } & \text { n.d. } & \text { n.d. } \\ \text { E } & 10-16 & \text { 7.5YR 4/2 } & 7 & 1.09 & 54 & 33 & 13 \\ \text { Bhs } & 16-24 & \text { 7.5YR 2/2 } & 23 & 1.01 & 49 & 31 & 19 \\ \text { Bs } & 24-55 & 7.5 \text { YR 3/4 } & 25 & 0.94 & \text { n.d. } & \text { n.d. } & \text { n.d. } \\ \text { BC } & 55-105 & \text { 10YR 5/4 } & 26 & 1.54 & 74 & 21 & 5 \\ \text { C } & 105-120 & \text { 10YR 6/4 } & 42 & 1.70 & 82 & 13 & 5\end{array}$

\section{Schmadri}

Profile 2

$\begin{array}{cccccccc}\text { O } & 0-8 & \text { 10YR 3/1 } & 5 & 0.57 & \text { n.d. } & \text { n.d. } & \text { n.d. } \\ \text { E } & 8-15 & \text { 10YR 4/1 } & 25 & 0.77 & 54 & 30 & 16 \\ \text { Bhs } & 15-22 & \text { 10YR 2/2 } & 27 & 1.36 & 51 & 32 & 17 \\ \text { Bs } & 22-50 & \text { 10YR4/4 } & 73 & 1.76 & \text { n.d. } & \text { n.d. } & \text { n.d. }\end{array}$




$\begin{array}{ccccccccc} & \text { C } & 50-85 & \text { 10YR 7/4 } & 80 & 1.89 & 78 & 17 & 5 \\ \text { Val Mulix } & & & & & & & & \\ & \text { O } & 0-13 & 5 \text { YR 1.7/1 } & 3 & 0.37 & 50 & 39 & 11 \\ & \text { E } & 13-20 & 7.5 \text { YR 1.7/1 } & 29 & 0.88 & 49 & 38 & 13 \\ & \text { Bhs } & 20-23 & \text { 5YR 2/2 } & 21 & 0.90 & \text { n.d. } & \text { n.d. } & \text { n.d. } \\ & \text { Bsm } & 23-50 & \text { 5YR 3/4 } & 61 & 1.75 & 82 & 15 & 3 \\ \text { BC } & 50-70 & 10 \text { YR 5/4 } & 54 & 1.68 & \text { n.d. } & \text { n.d. } & \text { n.d. } \\ & \text { C } & 70-100 & 10 \text { YR 6/3 } & 61 & 1.75 & 81 & 16 & 3\end{array}$

\begin{tabular}{ccccccccc} 
Meggerwald & & & & & & & \\
& A & $0-20$ & 7.5YR 2/3 & 13 & 0.87 & 48 & 35 & 17 \\
& Bw1 & $20-40$ & 10YR 4/4 & 20 & 1.11 & 46 & 39 & 15 \\
& Bw2 & $40-80$ & 10YR 4/4 & 26 & 1.42 & 49 & 38 & 14 \\
& BC & $80-130$ & 10YR 5/4 & 9 & 1.59 & n.d. & n.d. & n.d. \\
& 2C & $>130$ & 10YR 6/4 & 0 & 1.59 & 63 & 28 & 10 \\
\hline
\end{tabular}

n.d. $=$ not determined 
Table 3

Chemical characteristics of the soils (Favilli et al., 2009; Egli et al., 2009; Egli and Mirabella, 2001; Egli et al., 2003; Böhlert et al., submitted).

\begin{tabular}{|c|c|c|c|c|c|c|c|}
\hline Site/profile & $\begin{array}{c}\text { Soil } \\
\text { horizon }\end{array}$ & $\begin{array}{c}\mathrm{pH} \\
\left(\mathrm{CaCl}_{2}\right)\end{array}$ & $\begin{array}{l}\text { Org. C } \\
\text { g/kg }\end{array}$ & $\begin{array}{l}\mathrm{Fed}^{1)} \\
\mathrm{g} / \mathrm{kg}\end{array}$ & $\begin{array}{l}\mathrm{Ald}^{1)} \\
\mathrm{g} / \mathrm{kg}\end{array}$ & $\begin{array}{l}\mathrm{Feo}^{2)} \\
\mathrm{g} / \mathrm{kg}\end{array}$ & $\begin{array}{l}\mathrm{Alo}^{2)} \\
\mathrm{g} / \mathrm{kg}\end{array}$ \\
\hline \multirow[t]{5}{*}{ Val di Rabbi } & $\mathrm{AE}$ & 3.7 & 103.7 & 15.90 & 2.50 & 5.57 & 1.73 \\
\hline & $\mathrm{BE}$ & 3.6 & 61.0 & 20.50 & 2.80 & 6.06 & 1.91 \\
\hline & Bs1 & 4.1 & 39.4 & 44.10 & 14.70 & 19.62 & 10.27 \\
\hline & Bs2 & 4.4 & 17.0 & 21.40 & 7.30 & 9.37 & 5.84 \\
\hline & $\mathrm{BC}$ & 4.5 & 7.5 & 6.90 & 5.60 & 1.67 & 4.04 \\
\hline \multirow[t]{6}{*}{ Morteratsch } & $\mathrm{O}$ & 3.3 & 176.4 & 3.47 & 0.76 & 0.69 & 0.56 \\
\hline & $\mathrm{E}$ & 3.3 & 16.4 & 3.87 & 0.75 & 0.27 & 0.56 \\
\hline & Bs1 & 4.4 & 8.9 & 5.01 & 3.56 & 1.40 & 5.47 \\
\hline & Bs2 & 4.7 & 1.7 & 3.78 & 1.44 & 0.82 & 1.80 \\
\hline & $\mathrm{BC}$ & 4.9 & 0 & 3.47 & 1.11 & 0.40 & 1.16 \\
\hline & $\mathrm{C}$ & 4.9 & 0 & 3.28 & 0.83 & 0.33 & 0.90 \\
\hline \multicolumn{8}{|l|}{ Schmadri } \\
\hline \multirow{6}{*}{ Profile 1} & $\mathrm{O}$ & 3.9 & 383.3 & 4.59 & 2.71 & 3.26 & 2.10 \\
\hline & $\mathrm{E}$ & 3.7 & 22.3 & 1.83 & 0.77 & 0.45 & 0.84 \\
\hline & Bhs & 3.8 & 113.1 & 46.23 & 10.91 & 29.65 & 10.21 \\
\hline & Bs & 4.1 & 42.6 & 18.3 & 23.62 & 11.43 & 19.5 \\
\hline & $\mathrm{BC}$ & 4.5 & 9.5 & 7.83 & 4.37 & 2.67 & 4.48 \\
\hline & $\mathrm{C}$ & 4.7 & 2.2 & 4.84 & 1.65 & 1.23 & 1.48 \\
\hline \multicolumn{8}{|l|}{ Schmadri } \\
\hline \multirow[t]{5}{*}{ Profile 2} & $\mathrm{O}$ & 3.5 & 142.8 & 3.58 & 1.66 & 1.67 & 1.90 \\
\hline & $\mathrm{E}$ & 3.7 & 69.1 & 9.81 & 3.54 & 4.14 & 3.36 \\
\hline & Bhs & 3.8 & 112.6 & 13.08 & 7.74 & 7.28 & 7.61 \\
\hline & Bs & 4.3 & 45.5 & 20.78 & 12.92 & 11.72 & 13.38 \\
\hline & $\mathrm{C}$ & 4.7 & 6.0 & 2.79 & 2.41 & 1.41 & 2.32 \\
\hline
\end{tabular}


Val Mulix

$\begin{array}{ccccccc}\text { O } & 2.7 & 202.8 & \text { n.d. } & \text { n.d. } & \text { n.d. } & \text { n.d. } \\ \text { E } & 3.2 & 45.9 & 5.32 & 3.31 & 2.36 & 2.92 \\ \text { Bhs } & 3.5 & 50.5 & 17.91 & 8.48 & 10.30 & 7.03 \\ \text { Bsm } & 4.4 & 28.3 & 15.07 & 15.93 & 6.29 & 20.05 \\ \text { BC } & 4.4 & 3.9 & 2.84 & 2.54 & 1.20 & 3.25 \\ \text { C } & 4.6 & 2.3 & 1.69 & 1.66 & 0.79 & 2.04\end{array}$

Meggerwald

$\begin{array}{ccccccc}\text { A } & 3.8 & 35.0 & 10.91 & 5.78 & 5.51 & 4.75 \\ \text { Bw1 } & 4.1 & 11.0 & 11.13 & 4.10 & 3.89 & 3.41 \\ \text { Bw2 } & 4.3 & 6.0 & 10.35 & 4.60 & 3.01 & 3.71 \\ \text { BC } & 4.0 & 2.0 & 8.91 & 2.59 & 2.27 & 1.96 \\ \text { 2C } & 4.4 & 0 & 4.78 & 1.21 & 0.83 & 0.91\end{array}$

\footnotetext{
1) Dithionite-extractable content

${ }^{2)}$ Oxalate-extractable content n.d. $=$ not determined
} 
Table 4

Surface ages of the investigation sites

\begin{tabular}{|c|c|c|c|c|c|}
\hline Soil profile & y BP $\left({ }^{14} \mathrm{C}\right)$ & $\begin{array}{c}\text { y calBP } \\
(\text { OxCal })^{1}\end{array}$ & ${ }^{10} \mathrm{Be}$ age $(\mathrm{y})$ & Dated feature & References \\
\hline $\begin{array}{l}\text { Val di } \\
\text { Rabbi }\end{array}$ & $14410 \pm 110$ & $16782-17839$ & & $\begin{array}{l}\text { stable OM of a } \\
\text { lateral moraine } \\
\text { (Oldest Dryas) }\end{array}$ & Favilli et al., 2009 \\
\hline Morteratsch & & & $12460 \pm 1280$ & $\begin{array}{c}\text { boulder on a } \\
\text { lateral Egesen } \\
\text { moraine }\end{array}$ & $\begin{array}{c}\text { Maisch et al., } \\
2005\end{array}$ \\
\hline $\begin{array}{l}\text { Schmadri, } \\
\text { profile } 1\end{array}$ & $10390 \pm 150$ & $11751-12788$ & & $\begin{array}{c}\text { intramorainal peat } \\
\text { bog basis }\end{array}$ & Wipf, 2001 \\
\hline $\begin{array}{l}\text { Schmadri, } \\
\text { profile } 2\end{array}$ & $3330 \pm 85$ & $3381-3730$ & & $\begin{array}{l}\text { frontal moraine } \\
\text { above a fossile soil }\end{array}$ & Wipf, 2001 \\
\hline Val Mulix & & & $14690 \pm 1790$ & $\begin{array}{c}\text { boulder on a } \\
\text { lateral Daun } \\
\text { moraine }\end{array}$ & $\begin{array}{l}\text { Böhlert et al., } \\
\text { submitted }\end{array}$ \\
\hline Meggerwald & & $18000-19500$ & & $\begin{array}{l}\text { lateral and end } \\
\text { moraines, glacial } \\
\text { (retreat stadials at } \\
\text { the end of the } \\
\text { LGM }^{2} \text { : Hurden/ } \\
\text { Zürich stadial) }\end{array}$ & $\begin{array}{c}\text { Hantke, 1983; } \\
\text { Keller, 1988; } \\
\text { Keller and Krayss, } \\
\text { 2005; Maisch, } \\
\text { 2000; Zwahlen, } \\
\text { 2008 }\end{array}$ \\
\hline
\end{tabular}

${ }^{1} \mathrm{OxCal} 4.1$ calibration program (Bronk Ramsey, 2001) based on the IntCal 04 calibration curve (Reimer et al., 2004)

${ }^{2} \mathrm{LGM}=$ Lateglacial maximum 
Table 5

Cosmogenic nuclide inventories, estimated errors related to the estimation of the inventory and calculated age (including error range) using ${ }^{10} \mathrm{Be}$ deposition rates as a function of the amount of precipitation (Maejima et al., 2005). A) shows the age using ${ }^{10} \mathrm{Be}$ deposition rates as a function of the amount of precipitation and B) shows the calculated ages using a constant ${ }^{10} \mathrm{Be}$ deposition rate (Willenbring and von Blanckenburg, 2009).

\begin{tabular}{|c|c|c|c|c|c|c|c|c|c|}
\hline \multirow[t]{2}{*}{ Site } & \multirow{2}{*}{$\begin{array}{l}{ }^{10} \text { Be inventory } \\
(1 \mathrm{E}+8 ; \\
\left.\text { atoms } / \mathrm{cm}^{2}\right)\end{array}$} & \multicolumn{3}{|c|}{$\begin{array}{l}\text { Estimated errors } \\
\left(1 \mathrm{E}+8 ; \text { atoms } / \mathrm{cm}^{2}\right)\end{array}$} & \multirow{2}{*}{$\begin{array}{l}\text { Total error } \\
(1 \mathrm{E}+8 ; \\
\left.\text { atoms } / \mathrm{cm}^{2}\right)\end{array}$} & \multirow{2}{*}{$\begin{array}{c}{ }^{\text {A) Annual }}{ }^{10} \mathrm{Be} \\
\text { deposition rate } \\
\text { (atoms } / \mathrm{cm}^{2} \text {; } \\
1 \mathrm{E}+6)\end{array}$} & \multirow[t]{2}{*}{ 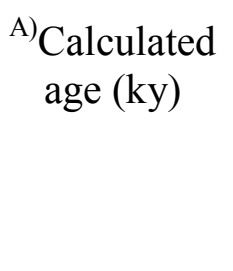 } & \multirow{2}{*}{$\begin{array}{c}{ }^{\mathrm{B})} \text { Annual }{ }^{10} \mathrm{Be} \\
\text { deposition rate } \\
\text { (atoms } / \mathrm{cm}^{2} \text {; } \\
1 \mathrm{E}+6)\end{array}$} & \multirow[t]{2}{*}{$\begin{array}{l}{ }^{\mathrm{B})} \text { Calculated } \\
\text { age (ky) }\end{array}$} \\
\hline & & Measurement & Density & Soil skeleton & & & & & \\
\hline Val di Rabbi & 158.0 & 5.1 & 6.7 & 5.0 & 16.8 & 1.21 & $13.1 \pm 1.4$ & 1.00 & $15.9 \pm 1.7$ \\
\hline Morteratsch & 125.8 & 7.7 & 6.3 & 5.8 & 19.8 & 1.33 & $9.5 \pm 1.5$ & 1.00 & $12.6 \pm 2.0$ \\
\hline $\begin{array}{l}\text { Schmadri, } \\
\text { profile } 1\end{array}$ & 283.8 & 12.7 & 14.2 & 4.1 & 31.0 & 2.43 & $11.7 \pm 1.3$ & 1.00 & $28.5 \pm 3.0$ \\
\hline $\begin{array}{l}\text { Schmadri, } \\
\text { profile } 2\end{array}$ & 147.3 & 5.5 & 7.4 & 19.1 & 32.0 & 2.43 & $6.0 \pm 1.3$ & 1.00 & $14.7 \pm 3.2$ \\
\hline Val Mulix & 214.5 & 9.4 & 10.7 & 14.7 & 34.8 & 1.51 & $14.3 \pm 2.3$ & 1.00 & $21.6 \pm 3.5$ \\
\hline Meggerwald & 301.0 & 17.2 & 9.0 & 3.7 & 29.9 & 1.57 & $19.2 \pm 1.7$ & 1.00 & $30.3 \pm 2.7$ \\
\hline
\end{tabular}


Table 6

Estimated erosion rates using (a) ${ }^{10} \mathrm{Be}$ deposition rates as a function of precipitation and (b) ${ }^{10} \mathrm{Be}$ deposition rates as constant flux (according to Field et al., 2006; Heikkilä, 2007; Willenbring and von Blanckenburg, 2009) and acting on the assumption of a ${ }^{10} \mathrm{Be}$ background-value (pre-exposure).

\begin{tabular}{lccc}
\hline Site & $\begin{array}{c}\text { Measured inventory } \\
\left({ }^{10} \text { Be atoms x 1E+8) }\right.\end{array}$ & $\begin{array}{c}\text { Expected inventory } \\
\left({ }^{10} \text { Be atoms x 1E+8) }\right.\end{array}$ & $\begin{array}{c}\text { Erosion rate } \\
(\mathrm{mm} / \mathrm{ky})\end{array}$ \\
\hline a) & & & \\
Val di Rabbi & 158.0 & 206.5 & $13.8-14.9$ \\
Morteratsch & 125.8 & 165.4 & $5.0-18.4$ \\
Schmadri, & & & $1.3-2.1$ \\
profile 1 & 283.8 & 290.7 & - \\
Schmadri, & 147.3 & & $4.3-6.2$ \\
profile 2 & 214.5 & 221.2 & $<1$ \\
Val Mulix & 301.0 & 300.0 & \\
Meggerwald & & & $26.7-30.5$ \\
b) & & 172.3 & $6.5-31.7$ \\
Val di Rabbi & 83.1 & 124.5 & $2.7-4.1$ \\
Morteratsch & 74.9 & 122.5 & - \\
Schmadri, & & & $5.5-57.1$ \\
profile 1 & 108.4 & 36 & $6.9-15.1$ \\
Schmadri, & & 144.5 & \\
profile 2 & 91.8 & 184.3 & \\
Val Mulix & 115.9 & & \\
Meggerwald & 171.7 & & \\
\hline
\end{tabular}

${ }^{1}$ The ${ }^{10} \mathrm{Be}$ concentration in the lowest soil horizon is assumed to reflect the pre-exposure. The inventory is calculated using the concentrations of the individual soil horizons minus the value measured in the lowest horizon. 